\title{
TRAIL and Taurolidine induce apoptosis and decrease proliferation in human fibrosarcoma
}

\author{
Adrien Daigeler*1, Christina Brenzel2 ${ }^{2}$ Daniel Bulut ${ }^{3}$, Anne Geisler2, \\ Christoph Hilgert ${ }^{2}$, Marcus Lehnhardt ${ }^{1}$, Hans U Steinau ${ }^{1}$, Annegret Flier ${ }^{1}$, \\ Lars Steinstraesser ${ }^{1}$, Ludger Klein-Hitpass ${ }^{4}$, Ulrich Mittelkötter ${ }^{2}$, \\ Waldemar $\mathrm{Uhl}^{2}$ and Ansgar M Chromik ${ }^{2}$
}

\begin{abstract}
Address: ${ }^{1}$ Department of Plastic Surgery, Burn Center, Hand Center, Sarcoma Reference Center, BG-University Hospital Bergmannsheil, Bürkle-dela-Camp-Platz 1, 44789 Bochum, Germany, ${ }^{2}$ Department of General and Visceral Surgery, St. Josef Hospital, Ruhr-University, Gudrunstraße 56, 44791 Bochum, Germany, ${ }^{3}$ Department of Medicine II, St. Josef Hospital, Ruhr-University, Gudrunstraße 56, 44791 Bochum, Germany and ${ }^{4}$ Institute for Cell Biology (Tumor Research), University of Duisburg-Essen, Virchowstraße 17345122 Essen, Germany

Email: Adrien Daigeler* - adrien.daigeler@rub.de; Christina Brenzel - christina.brenzel@rub.de; Daniel Bulut - daniel.bulut@rub.de; Anne Geisler - annergy@web.de; Christoph Hilgert - christoph.hilgert@rub.de; Marcus Lehnhardt - marcus.lehnhardt@rub.de; Hans U Steinau - hans-ulrich.steinau@bergmannsheil.de; Annegret Flier - lars.steinstraesser@rub.de; Lars Steinstraesser - annegret.flier@rub.de; Ludger Klein-Hitpass - ludger.klein-hitpass@uni-essen.de; Ulrich Mittelkötter - u.mittelkoetter@katharinen-hospital.de; Waldemar Uhl - waldemar.uhl@rub.de; Ansgar M Chromik - chromik@t-online.de

* Corresponding author
\end{abstract}

Published: 12 December 2008

Journal of Experimental \& Clinical Cancer Research 2008, 27:82 doi:10.1 186/1756-9966-27-82
Received: 27 October 2008

Accepted: 12 December 2008

This article is available from: http://www.jeccr.com/content/27/I/82

(c) 2008 Daigeler et al; licensee BioMed Central Ltd.

This is an Open Access article distributed under the terms of the Creative Commons Attribution License (http://creativecommons.org/licenses/by/2.0), which permits unrestricted use, distribution, and reproduction in any medium, provided the original work is properly cited.

\begin{abstract}
Background: Disseminated soft tissue sarcoma still represents a therapeutic dilemma because effective cytostatics are missing. Therefore we tested TRAIL and Tarolidine (TRD), two substances with apoptogenic properties on human fibrosarcoma (HTI080).

Methods: Viability, apoptosis and necrosis were visualized by TUNEL-Assay and quantitated by FACS analysis (Propidiumiodide/AnnexinV staining). Gene expression was analysed by RNAMicroarray and the results validated for selected genes by rtPCR. Protein level changes were documented by Western Blot analysis. NFKB activity was analysed by ELISA and proliferation assays ( $\mathrm{BrdU})$ were performed.
\end{abstract}

Results and discussion: The single substances TRAIL and TRD induced apoptotic cell death and decreased proliferation in HTI080 cells significantly. Gene expression of several genes related to apoptotic pathways (TRAIL: ARHGDIA, NFKBIA, TNFAIP3; TRD: HSPAIA/B, NFKBIA, GADD45A, SGK, JUN, MAP3K I 4) was changed. The combination of TRD and TRAIL significantly increased apoptotic cell death compared to the single substances and lead to expression changes in a variety of genes (HSPA IA/B, NFKBIA, PPPIRI 5A, GADD45A, AXL, SGK, DUSPI, JUN, IRFI, MYC, BAG5, BIRC3). NFKB activity assay revealed an antipodal regulation of the several subunits of NFKB by TRD and TRD+TRAIL compared to TRAIL alone.

Conclusion: TRD and TRAIL are effective to induce apoptosis and decrease proliferation in human fibrosarcoma. A variety of genes seems to be involved, pointing to the NFKB pathway as key regulator in TRD/TRAIL-mediated apoptosis. 


\section{Background}

Fibrosarcoma is a rare entity within the heterogeneous group of soft tissue sarcomas. It accounts for approximately $2.6 \%$ of soft tissue sarcomas which themselves have an incidence of about 2-4/100000 [1]. Surgical resection is the key factor in primary treatment and radiation can improve local control, but once the disease has spread, the remaining treatment options are very limited. Response rates to established chemotherapeutic agents like doxorubicin and ifosfamide (with up to 30\% at best) are still disappointing [2]. Therefore, new agents are being sought to broaden the therapeutic armament.

TRAIL (tumor necrosis factor receptor apoptosis inducing ligand) has previously been associated with apoptosis in a variety of malignant cells [3] and in HT1080 as well [4]. Whereas FasL (Fas Ligand) and TNF caused significant side effects by unselective apoptogenic effects on normal cells [5], TRAIL proved to be much less toxic and at least equally effective.

Many substances, including established chemotherapeutics like 5-Fluorouracil, cisplatin, doxorubicin, etoposide and others, like vitamime E succinate and alpha-Tocopheryl succinate have been shown to sensitize tumor cells to TRAIL-induced apoptosis [6-9]. Recent studies revealed apoptotic effects of another substance, Taurolidine, that was originally used as an antiinfective in peritonitis. Taurolidine exerted apoptotic activity on a variety of malignant cells in vitro and in vivo [10-12]. First reports of successful treatments of glioblastoma and advanced gastric cancer without systemic side effects in humans are promising $[13,14]$. Taurolidine has previously been shown to enhance Fas-Ligand mediated cell death [15] and a xenograft study using recombinant TNF in the treatment of mouse fibrosarcoma revealed that Taurolidine reduced the toxicity of TNF without decreasing the antitumor efficacy of TNF [16]. The detailed mechanism of action is still unclear, but inhibition of $\mathrm{Bcl}-2$ and an increased efflux of cytochrome-c, an activation of the caspases, and an increased PARP (poly (ADP-ribose) polymerase) cleavage seem to be involved $[10,17,18]$. By comparison, other authors found Fas-ligand dependent mechanisms or an inhibition of tumor angiogenesis to be responsible for the inhibition of tumor growth $[15,19]$.

In contrast to established chemotherapeutics, the absence of toxicity makes Taurolidine candidate for co-treatment with TRAIL. Inspired by previous studies that showed synergistic effects of TRAIL in combination with Taurolidine inducing apoptotic cell death in human colon and esophageal carcinoma cells [20,21], we examined the effects of these two substances on human fibrosarcoma.

\section{Methods \\ Cell line}

Human fibrosarcoma cells, HT1080, were purchased from ATCC (Cell line CCI 121, Wesel, Germany) and maintained with modified Eagle's medium (MEM) and NEAA (non-essential amino acids) $+10 \%$ FBS supplemented with $1 \%$ penicillin $(100 \mathrm{U} / \mathrm{ml})$ and streptomycin $(100 \mu \mathrm{g} /$ $\mathrm{ml}$ ), 1\% Sodium Pyruvate and 1\% L-Glutamine. Cells were cultured in a humidified atmosphere with $5 \% \mathrm{CO}_{2}$ at $37^{\circ} \mathrm{C}$ in $25 \mathrm{~cm}^{2}$ flasks.

\section{Reagents}

Taurolidine (TRD) (Taurolin ${ }^{\circledR} 2 \%$, Boehringer Ingelheim, Germany) containing 5\% Povidon was used as supplied by the manufacturer. A 5\% Povidon solution (K16 Povidon, generously provided by Geistlich Pharma AG, Wolhusen, Switzerland) in equal volume served as control for the TRD group. Recombinant human TRAIL/Apo2L (Bender MedSystems, Vienna, Austria) was dissolved in distilled water according to the manufacturer's instructions. Distilled water in equal volume served as control in the TRAIL experiments.

\section{Dose-finding study}

Cells were incubated with TRD $(50,100,250,500 \mu \mathrm{mol} /$

l) or recombinant human TRAIL $(10,50,100,500 \mathrm{ng} / \mathrm{ml})$ and the respective controls (Povidon/ $\mathrm{H}_{2} \mathrm{O}$ ) for 2, 6, 12, 24 $\mathrm{h}$ to identify effective single concentrations and the time dependency of the effects. All experiments were repeated with 3 consecutive passages.

The lowest effective single concentration TRAIL $50 \mathrm{ng} / \mathrm{ml}$ that induced apoptosis but no significant necrosis and TRD $250 \mu \mathrm{mol} / \mathrm{l}$, that showed the highest apoptotic rates and was most effective reducing viable cells were then used as single substances and in combination to identify a possibly synergistic effect. As time points 2, 6, 12, and 24 $\mathrm{h}$ were chosen. All experiments were repeated with 3 consecutive passages. Cells for gene expression were harvested after $2 \mathrm{~h}$.

\section{Flow cytometry analysis}

At the indicated incubation time, floating cells were collected together with the supernatant and adherent cells which were harvested by trypsinization. Cells were sedimented by centrifugation, resuspended in $195 \mu$ l binding buffer (Bender MedSystems, Vienna, Austria) and incubated with $5 \mu$ l Annexin V-FITC (BD Biosciences, Heidelberg, Germany) and $10 \mu$ Propidiumiodide (PI) (Bender MedSystems, Vienna, Austria) following the manufacturer's manual. Cells were analyzed immediately using a FACS flow cytometer (FACS Calibur BD Biosciences, Heidelberg, Germany). For each measurement, 20.000 cells were counted. Dot plots and histograms were analyzed by 
CellQuest Pro software (BD Biosciences, Heidelberg, Germany). Annexin V positive cells were considered apoptotic; Annexin V and PI positive cells were identified as necrotic. Annexin V and PI negative cells were termed viable.

\section{Cell morphology}

Morphology of adherent cells and cells suspended in culture medium was studied and documented using a phase contrast microscope, Zeiss Axiovert 25 (Karl Zeiss, Jena, Germany).

\section{TUNEL-assay}

Apoptosis was evaluated by terminal deoxynucleotidyl transferase-mediated dUTP-nick end-labeling (TUNEL) using the In Situ Cell Death Detection Kit, Fluorescein (Roche Applied Science, Mannheim, Germany) according to the manufacturer's instructions and analyzed by fluorescence microscopy (Leica DM4000B, Leica Microsystems, Nussloch, Germany).

\section{Annexin-PI staining for fluorescence microscopy}

Cells were incubated and prepared as for the TUNEL assay but stained with $5 \mu \mathrm{l}$ Annexin V-FITC and $10 \mu \mathrm{l}$ PI. Photos were taken immediately after staining using fluorescence microscopy (Leica DM4000B, Leica Microsystems, Nussloch, Germany).

\section{Proliferation-assay}

To determine and quantitate the effects of the different substances on cell proliferation, a colorimetric cell proliferation BrdU (5-bromo-2'-deoxyuridine)-ELISA (Roche Applied Science, Mannheim, Germany) was used according to the manufacturer's instructions. Based on the incorporation of the thymidine analogue BrdU during DNAsynthesis, the amount of newly synthesized DNA and thus of proliferation cells is detected using a microplate absorbance reader Sunrise ${ }^{\mathrm{TM}}$ (Tecan trading AG, Switzerland) after applying anti-BrdU conjugated with peroxidase (POD) and enhancing a specific substrate reaction. For this experiment, cells were incubated with the different substances for $8 \mathrm{~h}$.

\section{Statistical analysis}

Results of FACS-analysis for percentages of viable, apoptotic and necrotic cells are expressed as means \pm SD of at least three independent experiments with consecutive passages. In this study, comparisons between experimental groups (single agent application in different doses and single agents versus combined treatment at various time points) were performed using one way measures of variance (one way ANOVA) over all time points (Tukey). Pvalues $\leq 0.05$ were considered as statistically significant and indicated in the figures as follows: ${ }^{* * *} \mathrm{p} \leq 0.001, * *$ $\mathrm{p} \leq 0.005, * \mathrm{p} \leq 0.05$. The indications in figures $1,2,3$ refer to TRD $250 \mu \mathrm{mol} / \mathrm{l}$, TRAIL $50 \mathrm{ng} / \mathrm{ml}$, and TRD250 $\mu \mathrm{mol} / \mathrm{l}+\mathrm{TRAIL} 50 \mathrm{ng} / \mathrm{ml}$ compared to the control.

\section{Oligonucleotide microarray analysis}

To identify the changes on gene expression level caused by the treatment with TRAIL and TRD, total RNA was purified from the cells after incubation with the different substances for $2 \mathrm{~h}$ using the RNeasy KIT from Qiagen (Hilden, Germany), as specified by the manufacturer. RNA integrity was assessed using the Agilent 2100 Bioanalyzer (Agilent Technologies).

For microarray analyses, we used the Affymetrix GeneChip platform employing a standard protocol for sample preparation and microarray hybridization. Total RNA (5 $\mu \mathrm{g})$ was converted into biotinylated cRNA according to the Affymetrix standard protocol version 2, purified, fragmented and hybridized to HG-U133Plus_2.0 microarrays (Affymetrix). The arrays were washed and stained according to the manufacturer's recommendation and finally scanned in a GeneChip scanner 3000 (Affymetrix).

Array images were processed to determine signals and detection calls (Present, Absent, Marginal) for each probeset using the Affymetrix GCOS1.4 software (MAS 5.0 statistical algorithm). Arrays were scaled across all probesets to an average intensity of 1000 to compensate for variations in the amount and quality of the cRNA samples and other experimental variables of non-biological origin. Pairwise comparisons of treated versus control samples were carried out with GCOS1.4, which calculates the significance (change p-value) of each change in gene expression based on a Wilcoxon ranking test. To limit the number of false positives, we restricted further target identification to those probesets, which received at least one present detection call in the treated/control pair. Probesets exhibiting a significant increase or decrease were identified by filtering using the Affymetrix Data Mining Tool 3.0.

\section{Real-time PCR for microarray data validation}

Microarray data validation was performed for selected candidate genes (ARGHGDIA, BIRC3, GADD34, HSPA1A, HSPA1B, MAP3K14, MAP3K1). These were identified as the most differentially regulated ones in microarray analysis. Total RNA ( $2 \mu \mathrm{g}$ ) was reverse transcribed using the High Capacity cDNA Archive Kit (Applied Biosystems). Realtime PCR was done with a 7900 HT SDS system (Applied Biosystems) in $20 \mu$ reaction volume containing $1 \times$ Master Mix, $1 \mu \mathrm{l}$ assay and cDNA equivalent to $2 \mathrm{ng}$ total RNA. All reagents and realtime PCR assays (ARGHGDIA Hs00976924 g1, BIRC3 Hs00154109 m1, GADD34 Hs00169585 m1, HSPA1A Hs00359163 s1, HSPA1B $01040501+\mathrm{sH}, \mathrm{MAP} 3 \mathrm{~K} 14$ Hs01089753, MAP3K1 Hs00394890 m1) used were purchased from Applied Bio- 

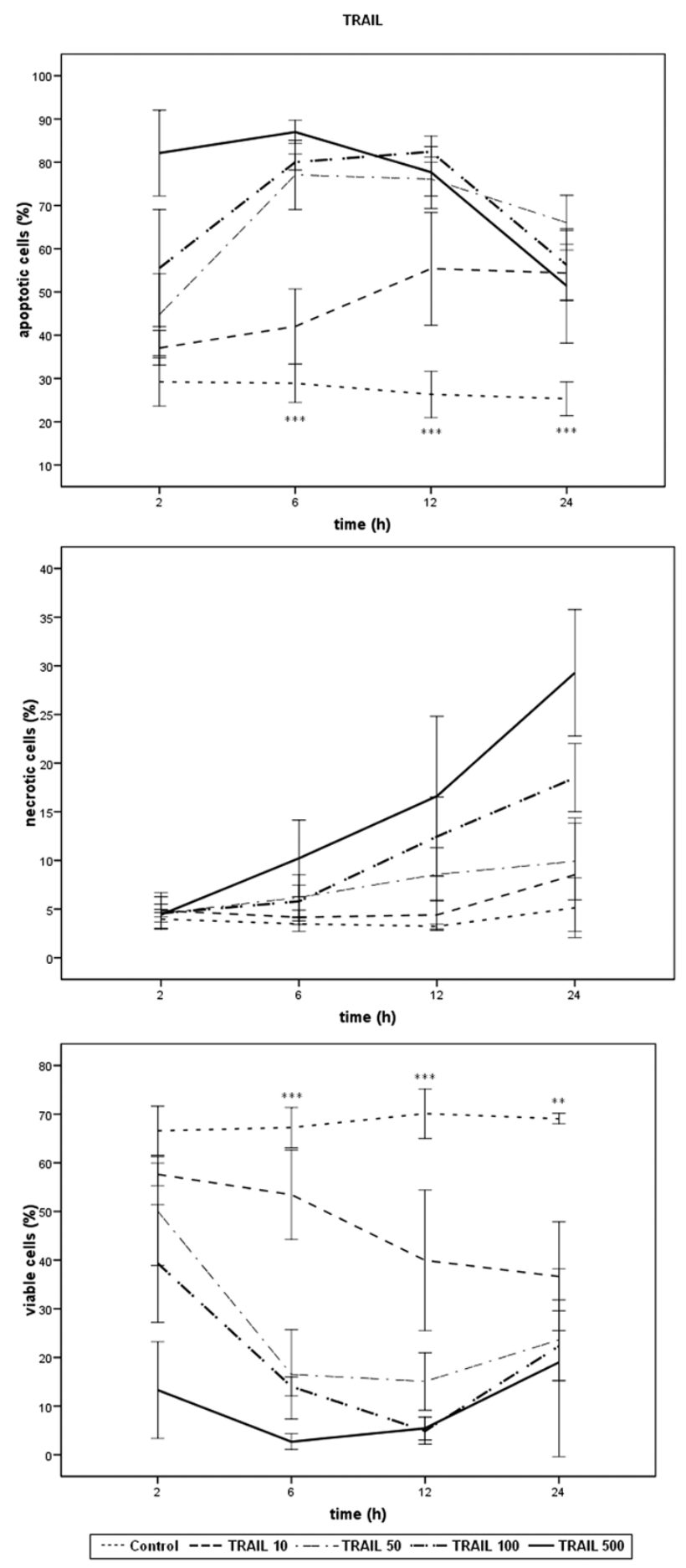

Figure I

Effects of TRAIL on viability, apoptosis and necrosis in HTI080 cells measured by FACS-analysis: Cells were incubated with TRAIL in the concentrations indicated and with $\mathrm{H}_{2} \mathrm{O}$ (control) for $24 \mathrm{~h}$. The percentages of viable, apoptotic and necrotic cells were determined by FACS-analysis for Annexin V-FITC and Propidiumiodide. Values are means \pm SD of 3 independent experiments with consecutive passage ( $* * * p \leq 0.001$, ** $p \leq 0.005$; one way ANOVA). The indicators of significance refer to the difference between the $50 \mathrm{ng} / \mathrm{ml}$ and the control series. The scales of the $y$-axis were adjusted to the different values for clarity and therefore vary. 

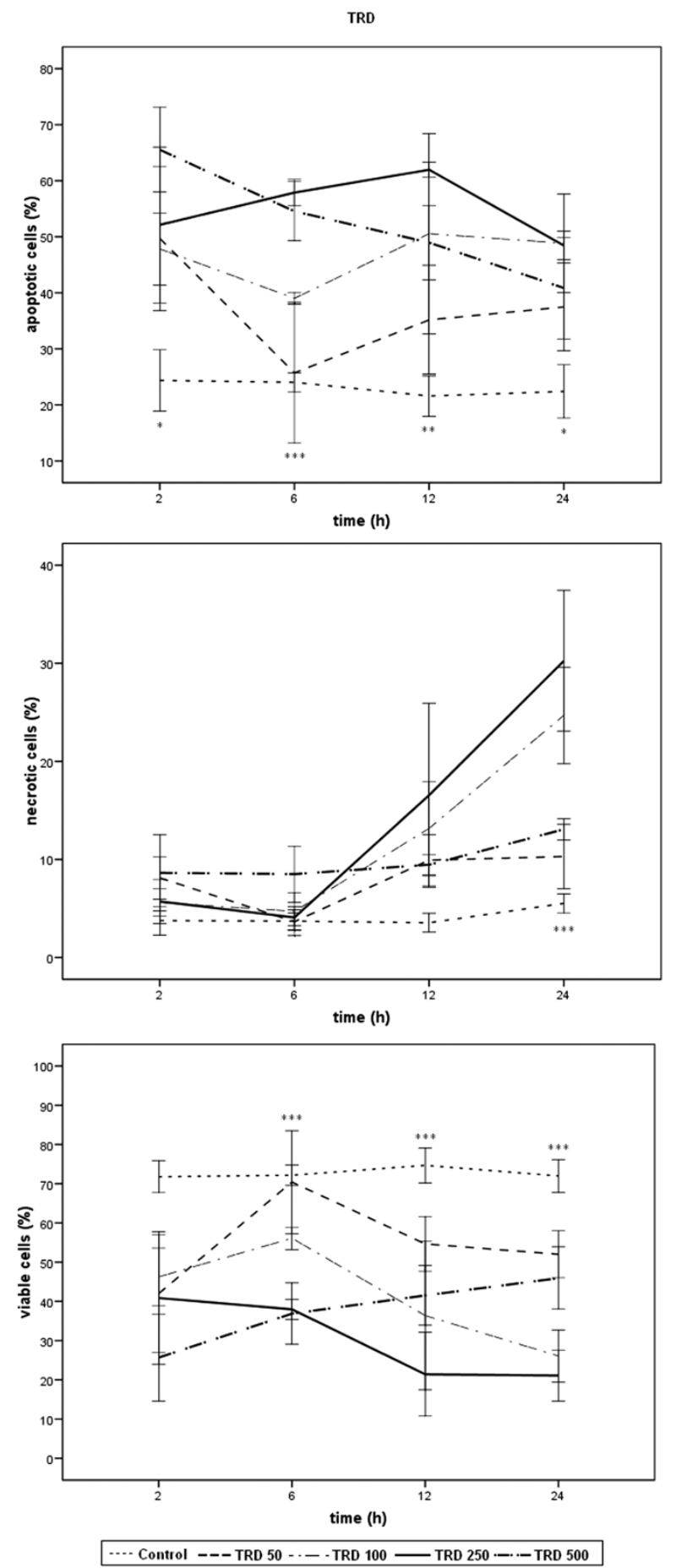

Figure 2

Effects of TRD on viability, apoptosis and necrosis in HTI080 cells measured by FACS-analysis: Cells were incubated with TRD in the concentrations indicated and with Povidon $5 \%$ (control) for $24 \mathrm{~h}$. The percentages of viable, apoptotic and necrotic cells were determined by FACS-analysis for Annexin V-FITC and Propidiumiodide. Values are means \pm SD of 3 independent experiments with consecutive passages. (*** $p \leq 0.001$, ** $p \leq 0.005$, $* p<0.05$; one way ANOVA). The indicators of significance refer to the difference between the $250 \mu \mathrm{mol} / \mathrm{l}$ and the control series. The scales of the $y$-axis were adjusted to the different values for clarity and therefore vary. 

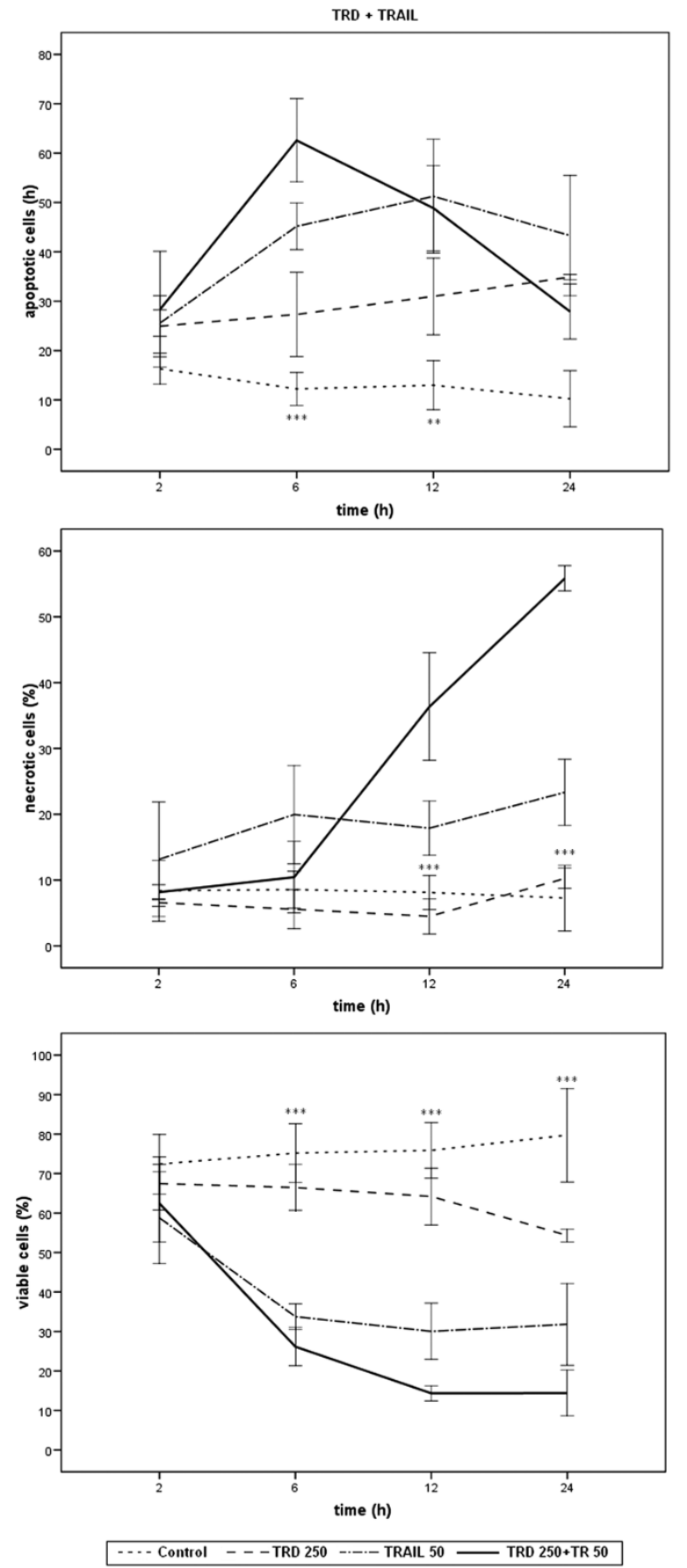

Figure 3

Effects of TRD, TRAIL and combination of both agents on viability, apoptosis and necrosis in HTI080 cells measured by FACSanalysis: Cells were incubated with $250 \mu \mathrm{mol} / / \mathrm{TRD}$ and $50 \mathrm{ng} / \mathrm{ml}$ TRAIL alone and in combination as well as with Povidon $5 \%$ $+\mathrm{H}_{2} \mathrm{O}$ (control) for $2 \mathrm{~h}, 6 \mathrm{~h}, \mathrm{I} 2 \mathrm{~h}$, and $24 \mathrm{~h}$. The percentages of viable, apoptotic and necrotic cells were determined by FACSanalysis for Annexin V-FITC and Propidiumiodide. Values are means \pm SD of 3 independent experiments with consecutive passages ( $* * * \mathrm{p} \leq 0.00 \mathrm{I}$, ** $\mathrm{p} \leq 0.005$; one way ANOVA). The indicators of significance refer to the difference between the TRD $250 \mu \mathrm{mol} / \mathrm{l}+$ TRAIL $50 \mathrm{ng} / \mathrm{ml}$ and the control series. The differences in the values compared to the single dose experiments are caused by experimental variability. The scales of the $y$-axis were adjusted to the different values for clarity and therefore vary. 
systems. Reactions were performed in duplicates and analysed by the deltadeltaCT method. Human GAPD was used for normalization.

\section{Western Blot}

To validate the findings of changed gene expression on protein level, Western Blots were performed using an SDSpage gel and the following antibodies (rabbit): Rho GDI $\alpha /$ ARGHGDIA (C-21), GADD 45 $\alpha$ (H-165), c-IAP2/BIRC3 (H-85), GADD 34/PPP1R15A (S-20), NIK/MAP3K14 (H$248)$, and $I \kappa B-\alpha / N F K B I A$ (C-21), purchased from Santa Cruz Biotechnology Inc. (Heidelberg, Germany). Total protein was purified from the cells after incubation with the different substances for two different time points $(2 \mathrm{~h}$ and $4 \mathrm{~h}$ ); for this purpose floating cells were collected together with the supernatant, adherent cells were harvested by trypsinization and added to the solution. Cells were sedimented by centrifugation. After removal of the supernatant, the probes were incubated with $50 \mu \mathrm{l}$ Cell Culture Lysis Reagent (Promega Corporation, Mannheim, Germany) each for $1 \mathrm{~h}$ on ice; the cell remnants then sedimented by centrifugation and the supernatant containing the purified protein deep frosted until further use.

Nuclear extract was derived from cells treated with the different substances for $4 \mathrm{~h}$ using the Nuclear Extract Kit (Aktive Motif Europe, Rixensart, Belgium) according to the manufacturer's instructions.

\section{NFKB-activity-ELISA}

The transcription factor $N F K B$ activity was detected and quantified using the TransAM ${ }^{\mathrm{TM}} N F K B$ Family Transcription Factor Assay Kit (Aktive Motif Europe, Rixensart, Belgium) according to the manufacturer's instructions and analyzed using a microplate absorbance reader Sunrise ${ }^{\mathrm{TM}}$ (Tecan trading AG, Switzerland). Nuclear extract, derived as specified above from cells treated with the different substances for 2 hours, was applied on a 96-well plate, to which oligonucleotide containing an NFKB consensus binding site has been immobilized. Activated NFKB specifically binds to these and was detected by using a primary antibody that is directed against the subunits $p 50$, p52, p65, c-Rel, and RelB. An HRP-conjugated secondary antibody provided a colorimetric readout that was spectophotometrically analysed.

\section{Results}

HT1080 fibrosarcoma cells are TRAIL sensitive. TRAIL as single agent caused apoptotic cell death time and dose dependently. TRAIL 100 and $500 \mathrm{ng} / \mathrm{ml}$ significantly induced early apoptosis after $2 \mathrm{~h}$ and resulted in a significant increase of necrotic cells at the following time points. TRAIL $50 \mathrm{ng} / \mathrm{ml}$, with $77.1 \%$ apoptotic cells, after $6 \mathrm{~h}$ reached almost the same efficiency concerning apoptosis but did not lead to comparable necrosis rates. Addition- ally, the effect on apoptosis lasted longer than in the 100 and $500 \mathrm{ng} / \mathrm{ml}$ group. At no time point did the percentage of necrotic cells significantly exceed the rates of necrotic cells of the control group. The lowest TRAIL concentration used $(10 \mathrm{ng} / \mathrm{ml})$ was significantly less effective in reducing viable cells than the other three concentrations (fig. 1). Therefore, TRAIL $50 \mathrm{ng} / \mathrm{ml}$ was used for the combination therapy.

TRD also induces apoptotic cell death in human HT1080 fibrosarcoma cells. The apoptogenic and necrosis inducing effects were dose and time dependent. The highest rate of apoptotic cells (after $12 \mathrm{~h}, 62.0 \%$ ) and the most effective reduction of viable cells (after $12 \mathrm{~h}, 21.1 \%$ ) was seen at a single concentration of $250 \mu \mathrm{mol} / \mathrm{l}$. The apoptotic and necrotic effects of TRD $50 \mu \mathrm{mol} / \mathrm{l}$ were only moderate and did not reach significance at any time point compared to the control. TRD 100 and TRD $500 \mu \mathrm{mol} / \mathrm{l}$ also induced significant apoptotic cell death but were less effective than the $250 \mu \mathrm{mol} / \mathrm{l}$ concentration over all time points. (fig. 2). Therefore, TRD $250 \mu \mathrm{mol} / 1$ was chosen to be applied together with TRAIL $50 \mathrm{ng} / \mathrm{ml}$.

\section{Combination of TRAIL $50 \mathrm{ng} / \mathrm{ml}$ and TRD 250 umolll}

After $6 \mathrm{~h}$ a significant increase of apoptotic cells (62.6\%) was detected compared to TRAIL $(\mathrm{p}=0.049)$ and TRD ( $\mathrm{p}$ $=0.001)$ as single substances as well as compared to the control ( $\mathrm{p}<0.001)$, while necrosis was not significantly increased. After $12 \mathrm{~h}$ and $24 \mathrm{~h}$, the necrotic proportion of cells increased and was significantly higher than in the single substances and the control group $(\mathrm{p}<0.001)$, while the amount of apoptotic cells decreased again. The combination therapy reached the peak of apoptotic rates earlier and could transduce apoptotic cells to cell death more quickly, thereby reducing the proportion of viable cells more effectively (after $12 \mathrm{~h}$, viable cells: 14.3\%) than the single substances. TUNEL assay and cytochemistry also showed qualitatively against the control that cells treated with TRD/TRAIL, TRAIL, and TRD underwent apoptotic cell death (data not shown).

\section{TRD and TRDITRAIL induce morphological changes and cell detachment}

TRAIL incubation did not change the cells' morphology and did not cause a detachment of the cells from the ground as shown by bright-field microscopy. TRD as single substance and the combination of TRD and TRAIL resulted in shrinkage of the cells, followed by complete cell detachment (fig. 4).

TRD, TRAIL and the combination therapy reduced proliferation of HT1080 significantly compared to the control ( $\mathrm{p}<0,001)$ as indicated by the BrdU-Assay (fig. 5). The combination therapy could not add to this effect compared to the incubation with TRD alone $(\mathrm{p}=1.0)$, but 
reduced proliferation significantly compared to TRAIL alone $(\mathrm{p}<0.001)$. The anti-proliferative potency of TRD was significantly higher than that of TRAIL ( $<<0.001)$.

\section{Gene expression}

In this experiment we selectively focussed on apoptosis related probesets. Out of 621 of those probesets, 174, representing 138 apoptosis related genes, showed expression changes (fig. 6). TRD alone induced differences in the expression of 67 apoptosis related genes, of which 22 were "upregulated"; by comparison, TRAIL as a single substance caused expression changes of 36 genes related to apoptotic pathways, "upregulating" 22 of them. TRD and TRAIL in combination induced changes in the expression of 65 genes ( 29 upregulated, 28 downregulated) A list of these genes, including the log ratios of the expression changes, is given in table 1 . Further filtering of the results, leaving only the genes whose expression changes that had a signal log ratio above 1 or below -1 , reduced the number of differentially regulated genes in this experiment to 21 (25 probe sets) (fig. 7). The expression of selected candidate genes was re-evaluated by rtPCR, revealing a largely good correlation (table $2 \mathrm{a} / \mathrm{b}$ ).

Further analysis of the translation of the candidate genes after 2 and $4 \mathrm{~h}$ tested in the rtPCR was performed by Western Blot. The results are presented in figure 8 . The results for NFKBIA, PPP1R15A, MAP3K14corresponded well to the rtPCR and microarray data, whereas the findings for ARHGDIA were partly oppositional to them. The other proteins (GADD45A, BIRC3) showed no such noticeable changes.

The transcription factor $N F K B$ activity was measured by quantifying its subunits $p 50, p 52, p 65, c-R e l$, and RelB. The results for the several subunits are illustrated in figure 9 .

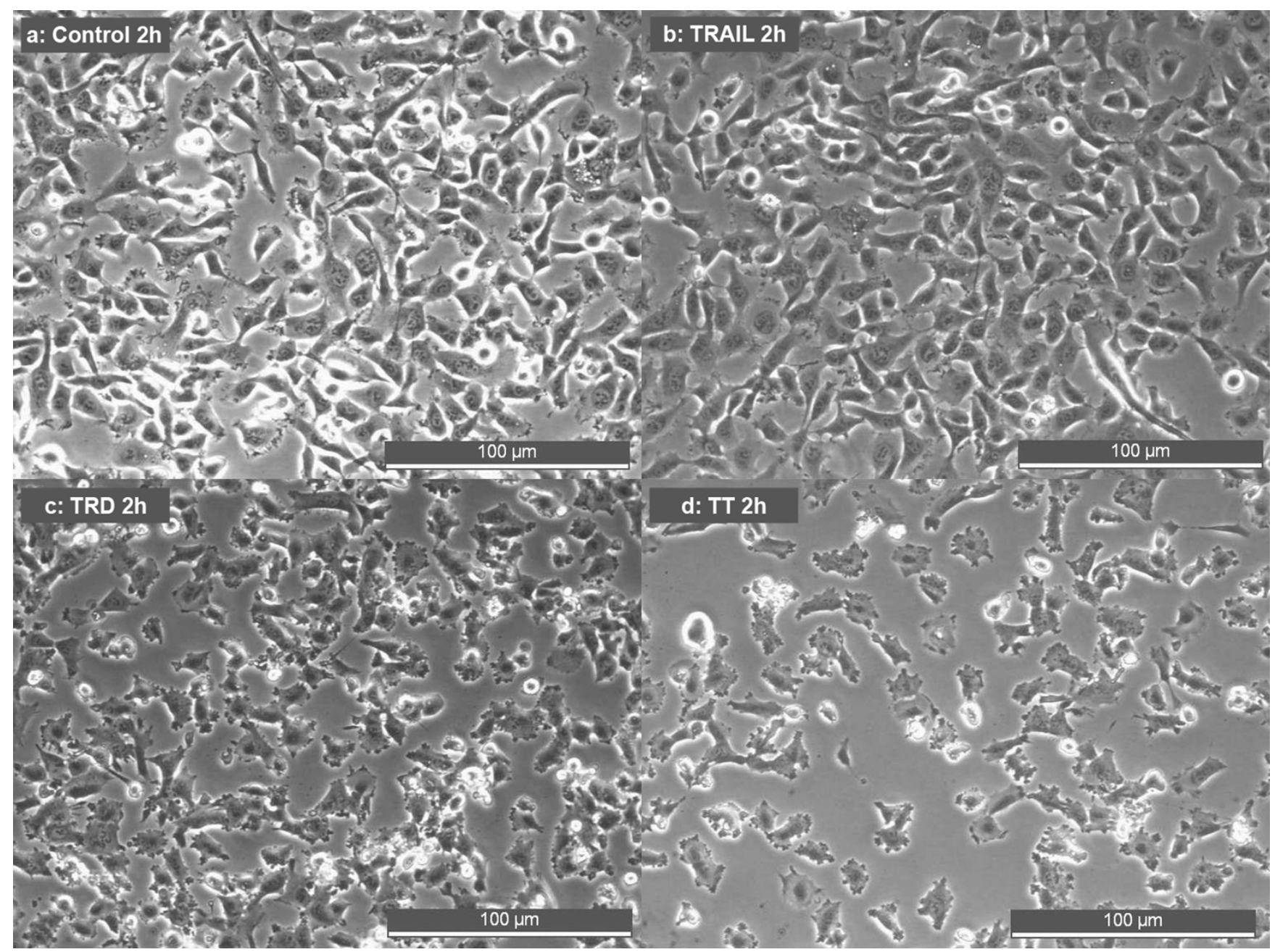

\section{Figure 4}

Phase contrast microscopic photographs showing morphologic changes induced by TRD, TRAIL and combination of both agents after $2 \mathrm{~h}$ : Cells were incubated with Povidon $5 \%+\mathrm{H}_{2} \mathrm{O}$ (control) (a), $50 \mathrm{ng} / \mathrm{ml}$ TRAIL (b), $250 \mu \mathrm{mol} / \mathrm{l} \mathrm{TRD} \mathrm{(c)} \mathrm{and} \mathrm{a}$ combination of TRD/TRAIL (d). 


\section{BrdU}

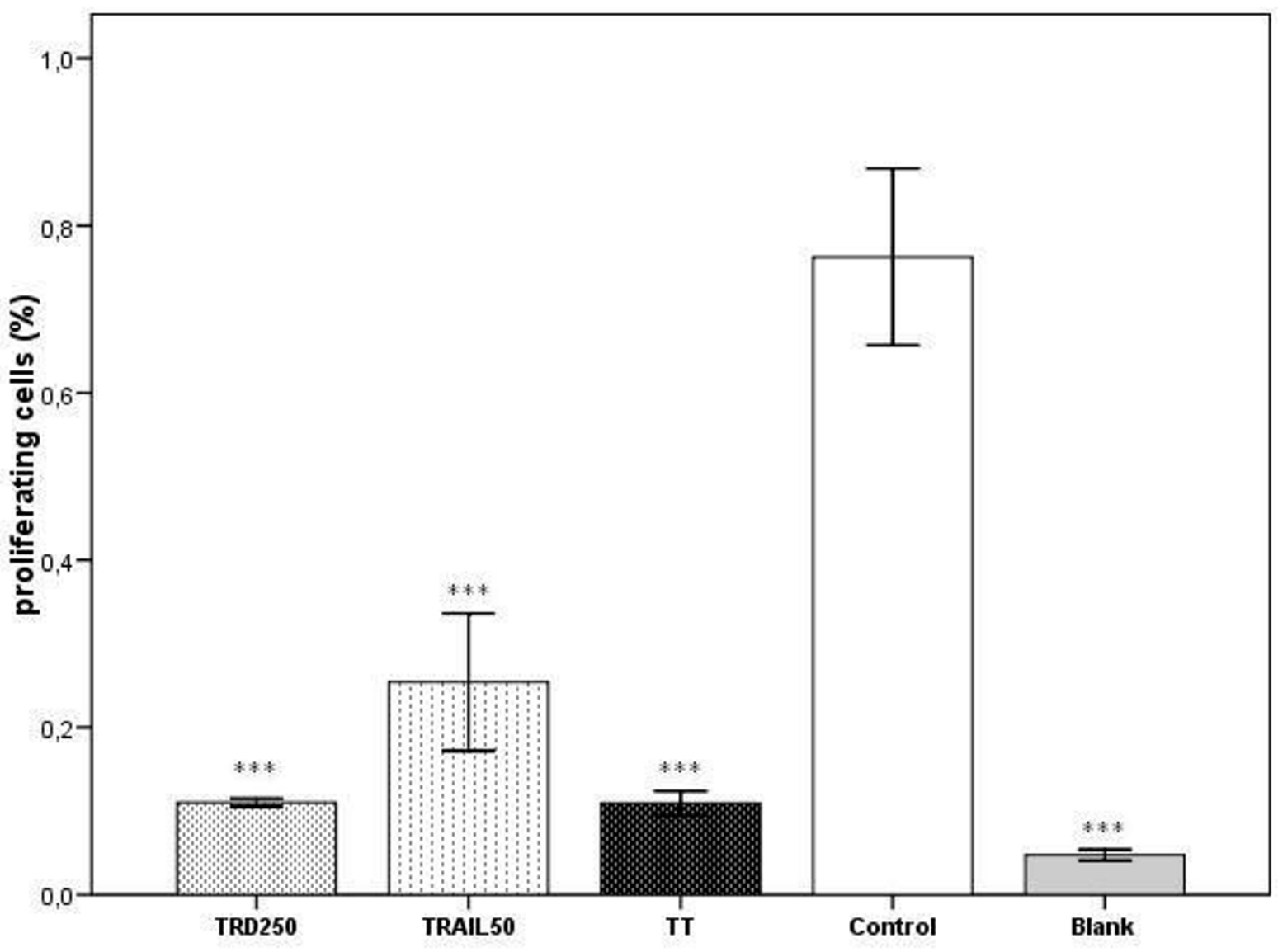

Figure 5

Effects of TRD, TRAIL and combination of both agents on proliferation were measured by BrdU cell proliferation-assay. Cells were incubated for $8 \mathrm{~h}$ with Povidon $5 \%+\mathrm{H}_{2} \mathrm{O}$ (control) (a), $50 \mathrm{ng} / \mathrm{ml}$ TRAIL (b), $250 \mu \mathrm{mol} / \mathrm{l} \mathrm{TRD} \mathrm{(c)} \mathrm{and} \mathrm{a} \mathrm{combination} \mathrm{of}$ TRD/TRAIL (d). A blank negative control (e) was used to document absence of proliferation.

Although the changes of the single substances and the combination therapy compared to the control were not significant, it is noteworthy that the changes of TRD and TRAIL/TRD were always more pronounced than those of TRAIL as single substance.

\section{Discussion}

To date, several reports suggested TRAIL as a promising substance in the treatment of sarcoma, especially when combined with other cytostatics.

Several studies found, that TRAIL was effective inducing apoptotic cell death and that the combination therapy of TRAIL and doxorubicin could overcome TRAIL resistance in a variety of soft tissue sarcoma cells [22].

In this study, TRAIL as a single substance effectively induced apoptotic cell death in HT1080 fibrosarcoma cells. Notably, only three genes (ARHGDIA, TNFAIP3, NFKBIA) were differentially up-regulated more than twofold compared to the control: ARHGDIA (Rho Guanosine Diphosphate-Dissociation Inhibitor A), that inhibits dissociation of Guanosine Diphosphate (GDP) from RhoA, thereby preventing it from binding GTP (Guanosine Triphosphate) and inactivating it. RhoA, an important regulator of the cytoskeleton, cell adherence and cell motility, is associated to the occurrence of metastases in several tumors $[23,24]$. In HT1080 cells that show high levels of Rho-GTP the inhibition of Rho by fasudil, a Rho kinase inhibitor, leads to decreased tumor cell motility and growth [25]. The findings that gene expression of ARHG$D I A$ was decreased by the combination therapy and by TRD, whereas the protein could be detected at much higher cytosolic concentrations after treatment with TRAIL and TRD, so far cannot be explained but may be the reason for cell detachment and the changes in cell mor- 
Table I: Additional information about the genes whose expression was changed more than two-fold in the experiments.

\begin{tabular}{|c|c|c|c|c|c|c|c|c|c|}
\hline $\begin{array}{l}\text { Gene } \\
\text { Symbol }\end{array}$ & $\begin{array}{l}\text { Ta250 vs } \\
\text { Co Signal } \\
\text { Log Ratio }\end{array}$ & $\begin{array}{l}\text { Gene } \\
\text { Symbol }\end{array}$ & $\begin{array}{l}\text { TR50 vs Co } \\
\text { Signal Log } \\
\text { Ratio }\end{array}$ & $\begin{array}{l}\text { Gene } \\
\text { Symbol }\end{array}$ & $\begin{array}{l}\text { Ta+TR vs } \\
\text { Co Signal } \\
\text { Log Ratio }\end{array}$ & $\begin{array}{l}\text { Gene } \\
\text { Symbol }\end{array}$ & $\begin{array}{c}\text { Ta+TR vs } \\
\text { Ta250 Signal } \\
\text { Log Ratio }\end{array}$ & $\begin{array}{l}\text { Gene } \\
\text { Symbol }\end{array}$ & $\begin{array}{c}\text { Ta+TR vs } \\
\text { TR50 Signal } \\
\text { Log Ratio }\end{array}$ \\
\hline HSPAIA/B & 2,99 & ARHGDIA & 1,19 & HSPAIA/B & 3,28 & TIEI & 0,89 & HSPAIA/B & 2,96 \\
\hline NFKBIA & 2,03 & NFKBIA & 1,17 & NFKBIA & 2,47 & $A X L$ & 0,85 & GADD45A & 1,55 \\
\hline GADD45A & 1,33 & TNFAIP3 & 1,11 & PPPIRI5A & 1,55 & IRF2 & 0,76 & SGK & 1,45 \\
\hline SGK & 1,22 & JUN & 0,89 & GADD45A & 1,46 & ERBB2 & 0,71 & NFKBIA & 1,3 \\
\hline JUN & $\mathrm{I}, 2$ & EGFR & 0,86 & $A X L$ & $|, 4|$ & RELA & 0,69 & PPPIRI5A & 1,22 \\
\hline PPPIRI5A & 0,95 & CALR & 0,85 & SGK & 1,37 & TIAFI & 0,69 & $A X L$ & 1,16 \\
\hline $\mathrm{MCLI}$ & 0,94 & TP53 & 0,64 & DUSPI & 1,33 & TIMP3 & 0,67 & MYC & $|, 0|$ \\
\hline DUSPI & 0,82 & TNK2 & 0,58 & JUN & $|, 3|$ & DUSP5 & 0,66 & DUSPI & 0,98 \\
\hline MYC & 0,78 & PPP2CB & 0,57 & IRFI & 1,23 & PPPIRI5A & 0,61 & IRFI & 0,84 \\
\hline BTGI & 0,7 & BAX & 0,51 & MYC & 1,05 & LITAF & 0,6 & BTGI & 0,84 \\
\hline IRFI & 0,69 & IRFI & 0,47 & BTGI & 0,85 & IRFI & 0,6 & $\mathrm{BCL} 2 \mathrm{Al}$ & 0,52 \\
\hline$A X L$ & 0,64 & IKBKG & 0,44 & DUSP5 & 0,65 & TP53 & 0,57 & BAGI & 0,46 \\
\hline RPS3A & 0,48 & BCL2LI & 0,44 & TIEI & 0,63 & TYRO3 & 0,55 & NEUI & 0,41 \\
\hline LDHB & 0,44 & $\mathrm{AXL}$ & 0,42 & NEUI & 0,63 & LTBR & 0,55 & JUN & 0,39 \\
\hline ESD & 0,43 & PPP2RIA & 0,41 & HD & 0,63 & TYK2 & 0,54 & ANXA4 & 0,37 \\
\hline HSPDI & 0,42 & CD44 & 0,38 & TNFAIP3 & 0,55 & SIPAI & 0,54 & GSTPI & 0,31 \\
\hline RPS3A & 0,41 & TIEI & 0,37 & CDKNIA & 0,55 & TRAF4 & 0,53 & CROP & $-0,24$ \\
\hline NMEI & 0,41 & DUSP3 & 0,37 & ACTN4 & 0,5 & DOCKI & 0,53 & CASP8 & $-0,24$ \\
\hline LGALSI & 0,4 & ACTN4 & 0,34 & EPHA2 & 0,48 & CSK & 0,52 & PPMID & $-0,31$ \\
\hline ENOI & 0,38 & PEAI5 & 0,32 & GSTPI & 0,47 & ACINI & 0,52 & API5 & $-0,32$ \\
\hline STKI7A & 0,3 & DAPK 3 & 0,31 & PPMIG & 0,45 & ARHGDIA & 0,49 & TNFRSFIOB & $-0,34$ \\
\hline API5 & $-0,14$ & ACINI & 0,31 & TIAFI & 0,44 & $\mathrm{ABCA} 2$ & 0,48 & FOXOI & $-0,37$ \\
\hline DDR2 & $-0,15$ & BID & $-0,23$ & CFLI & 0,4 & TNFRSF25 & 0,47 & RAD2I & $-0,38$ \\
\hline PDCD4 & $-0,17$ & MAP3K5 & $-0,27$ & LITAF & 0,37 & TNFRSFIA & 0,47 & EGFR & $-0,39$ \\
\hline E2FI & $-0,18$ & FER & $-0,27$ & PINKI & 0,36 & FGFRI & 0,47 & DUSPIO & $-0,45$ \\
\hline LITAF & $-0,2$ & FAS & $-0,3$ & RPS3A & 0,35 & DNM2 & 0,47 & NFKBI & $-0,46$ \\
\hline EPHB2 & $-0,21$ & CROP & $-0,33$ & LGALSI & 0,32 & NFKBIA & 0,45 & $\mathrm{FOXO} 3$ & $-0,46$ \\
\hline FGFRI & $-0,22$ & HSPA9 & $-0,37$ & PPPICA & 0,29 & $\mathrm{EPHB} 2$ & 0,45 & RYBP & $-0,49$ \\
\hline RIPKI & $-0,22$ & CHUK & $-0,4$ & ENOI & 0,28 & IRF3 & 0,42 & MCLI & $-0,49$ \\
\hline CSK & $-0,25$ & LYN & $-0,43$ & MAP3KI & $-0,04$ & DDR2 & 0,42 & DUSP3 & $-0,53$ \\
\hline TIEI & $-0,25$ & CUL2 & $-0,47$ & DUSPIO & $-0,21$ & WEEI & 0,38 & BCLAFI & $-0,56$ \\
\hline TNFRSF2I & $-0,25$ & TIAI & $-0,49$ & FAS & $-0,22$ & E2FI & 0,36 & TP53 & $-0,58$ \\
\hline ACINI & $-0,28$ & PPMIB & $-0,55$ & MCLI & $-0,26$ & BAKI & 0,36 & HELLS & $-0,61$ \\
\hline РPР3СB & $-0,28$ & CASP8 & $-0,68$ & CUL4A & $-0,26$ & PPMIG & 0,34 & PPP2CB & $-0,62$ \\
\hline CHUK & $-0,29$ & MCLI & $-0,7$ & FADD & $-0,27$ & FYN & 0,31 & DAPK3 & $-0,64$ \\
\hline DAPK3 & $-0,29$ & & & TIAI & $-0,28$ & RYK & 0,3 & TNFAIP3 & $-0,67$ \\
\hline PPP2RIB & $-0,29$ & & & PAWR & $-0,29$ & DUSPI & 0,3 & SOCS2 & $-0,71$ \\
\hline YWHAH & $-0,29$ & & & РPP3CC & $-0,31$ & ACTN4 & 0,3 & CLKI & $-0,72$ \\
\hline RYK & $-0,34$ & & & FOXO3 & $-0,32$ & CTSB & 0,28 & IKBKG & $-0,74$ \\
\hline MAP3KII & $-0,35$ & & & TIAI & $-0,34$ & HSPAIA/B & 0,25 & BAG5 & $-0,97$ \\
\hline BCLAFI & $-0,36$ & & & RIPK2 & $-0,34$ & SARTI & 0,24 & BCL2LI & $-0,99$ \\
\hline DOCKI & $-0,4$ & & & SOCS2 & $-0,37$ & $\mathrm{DHCR} 24$ & 0,24 & CLK4 & $-1,02$ \\
\hline$F 2 R$ & $-0,4$ & & & CASP7 & $-0,37$ & JUN & 0,23 & MET & $-1,05$ \\
\hline SIAHI & $-0,41$ & & & CALR & $-0,37$ & PPP4C & 0,22 & CALR & $-1,23$ \\
\hline $\mathrm{AHR}$ & $-0,44$ & & & WEEI & $-0,38$ & PPP2RIA & 0,21 & MAP3KI & $-1,32$ \\
\hline CASP8 & $-0,47$ & & & API5 & $-0,39$ & GSTPI & 0,21 & MAP3KI4 & $-1,34$ \\
\hline DUSPIO & $-0,48$ & & & MAP2K4 & $-0,41$ & YWHAH & 0,2 & CASP2 & $-1,7$ \\
\hline MET & $-0,51$ & & & ABL2 & $-0,42$ & PDCD4 & 0,18 & ARHGDIA & $-1,95$ \\
\hline TP53 & $-0,52$ & & & CUL2 & $-0,44$ & FXRI & $-0,24$ & BIRC3 & $-2,32$ \\
\hline ABL2 & $-0,54$ & & & PPP2RIB & $-0,45$ & $\mathrm{PHB}$ & $-0,28$ & & \\
\hline IKBKG & $-0,54$ & & & SIAHI & $-0,46$ & YESI & $-0,29$ & & \\
\hline RELA & $-0,54$ & & & PPMID & $-0,46$ & CUL2 & $-0,38$ & & \\
\hline ARHGDIA & $-0,55$ & & & CHUK & $-0,5$ & CUL4A & $-0,39$ & & \\
\hline SOCS2 & $-0,55$ & & & BCL2LI & $-0,54$ & CASP7 & $-0,42$ & & \\
\hline TIMP3 & $-0,55$ & & & TIAI & $-0,56$ & BCLAFI & $-0,42$ & & \\
\hline CASP2 & $-0,59$ & & & CASP2 & $-0,56$ & CASP8 & $-0,49$ & & \\
\hline CROP & $-0,59$ & & & RYBP & $-0,63$ & MET & $-0,53$ & & \\
\hline PRFI & $-0,64$ & & & BCLAFI & $-0,64$ & TFG & $-0,84$ & & \\
\hline
\end{tabular}


Table I: Additional information about the genes whose expression was changed more than two-fold in the experiments. (Continued)

\begin{tabular}{|c|c|c|c|c|c|}
\hline CALR & $-0,65$ & ARHGDIA & $-0,74$ & MCLI & -1, \\
\hline WEEI & $-0,66$ & CROP & $-0,78$ & & \\
\hline ERBB2 & $-0,8$ & CLKI & $-0,88$ & & \\
\hline CLK4 & $-0,81$ & MET & $-0,91$ & & \\
\hline BCL2LI & $-0,82$ & CASP8 & $-0,97$ & & \\
\hline BAG5 & $-0,9$ & CLK4 & $-0,99$ & & \\
\hline CLKI & $-0,92$ & BAG5 & $-1,08$ & & \\
\hline MAP3К 44 & $-1,35$ & BIRC3 & $-1,45$ & & \\
\hline
\end{tabular}

phology. The fact that the Western Blot findings after $4 \mathrm{~h}$ corresponded much better to the findings after $2 \mathrm{~h}$ may be caused by the time translation takes to increase cytosolic protein concentration.

TNFAIP3, that was found to be up-regulated by TRAIL in our study, is an inhibitor of the NFKB pathway [26] and may thereby promote apoptosis but, on the other hand, it was shown to decrease TNF-mediated apoptosis and necrosis [27], leaving its specific influence unclear.

NFKBIA is an inhibitor of $N F K B$, which has been associated with resistance to chemotherapeutics such as doxorubicin [28]. The doxorubicin analogon DA-125 could reduce proliferation in HT1080 fibrosarcoma cells through a NFKB dependent pathway [29] and recent studies showed that tumor invasiveness could be significantly reduced by inhibiting NFKB activity [30], pointing to this transcription factor as a key element in HT1080 proliferation-pathways. In our study, NFKBIA was found to be over-expressed on gene and on protein level after TRAIL, TRD and the combination therapy.

As previously reported, TRD lacks toxic short or long term effects but has the ability to induce apoptotic cell death in a variety of malignant cells. In several osteosarcoma cell lines, TRD has already been shown to induce apoptosis and decrease cell adhesion [31], but to the authors' knowledge TRD or the combination of TRAIL and TRD has not yet been investigated on soft tissue sarcoma. Interestingly, Taurolidine was shown to reduce toxicity of TNF in vivo without reducing its antitumoral activity; probably by interfering not with TNF directly but with its downstream pathway, which is largely the same for TRAIL $[16,32]$, qualifying this substance for co-treatment with TRAIL.

The changes in cell morphology and detachment of the cells from the ground that were observed after incubation with TRD may be explained by the finding of other studies; TRD reduced the expression of integrins and cadherins in colon cancer cells and reduced intraperitoneal metastases and tumor growth accordingly [33].

Gene expression profiling revealed a small number of genes whose expression was changed more than two-fold.
Among them, the heat shock protein $H S P A 1 A / B$. Increased expression of this protein was associated with increased chemosensitivity of HT1080 to mitomycin C [34]. Furthermore, the apoptogenic effects of taxanes on sarcoma could be increased by co-therapy with STA-4783, a stimulator of HSPA1A expression [35]. NFKBIA, that was also up-regulated by TRD, has already been mentioned. Notably, there are reports that TRD inhibits the activation of $N F K B$ not only indirectly through NFKBIA but, also by direct interference, by oxidation of $N F K B$ at Met45 [36].

Upregulation of GADD45A was shown to be associated with increased apoptosis and p53 independent cell cycle arrest in a variety of soft tissue sarcomas [37].

It inhibits transcription factors associated with tumor growth such as JNK (c-Jun N-terminal kinase) and NFKB $[38,39]$. For rhabdomyosarcoma, increased GADD45A was associated with less aggressive tumor behaviour [40]. Additionally GADD45A may antagonize TNF-receptor mediated cytotoxicity [41]. SGK, that was also found to be up-regulated in contrast to most of the other differentially expressed genes can activate the NFKB pathway and thereby prevent cells from undergoing apoptosis [42]. In this context, this effect seems to be outweighed by other proapoptotic ones. JUN is activated JNK dependently and promotes apoptotic cell death in malignant cells including osteosarcoma [43]. Downregulation of JUN was shown to decrease the expression of matrix metalloproteinases and thereby cellular invasiveness in HT1080 cells [44]. This downregulation may be mediated through suppression of $N F K B$ activation [45]. MAP3K14, the only gene that was down-regulated more than two-fold by TRD, is a member of the TNF-pathway and activates NFKB (IKKalpha)

The significant increase in apoptosis and necrosis using the combination of the two substances was accompanied by a large number of expression changes. Therefore, we will not further discuss the ones that were already described in the TRAIL and TRD section of the discussion; we summarized the remaining genes and their functions in table 3. Interestingly, there was only one gene with twofold expression changes when the TRD/TRAIL cells were compared to those that were incubated with TRD alone: 
Table 2:

\begin{tabular}{|c|c|c|c|c|c|c|c|c|c|c|c|}
\hline \multicolumn{12}{|c|}{ a: Summary of the selected candidate genes' microarray data (Istands for no value). } \\
\hline $\begin{array}{l}\text { Microarray } \\
\text { Probeset }\end{array}$ & $\begin{array}{r}201167 \text { _at } \\
\text { _at }\end{array}$ & $\begin{array}{r}201168 \text { _at } \\
\text { _at }\end{array}$ & 210538 _s_ & 202014_at & 203725_at & 200799_at & 200800 s_ & 20258I_at & 214786_at & 205192_at & 201502 s \\
\hline $\begin{array}{l}\text { Gene } \\
\text { Symbol } \\
\text { SLR = } \\
\text { log2(RQ) }\end{array}$ & ARHGDIA & $\begin{array}{r}\text { ARHGDIA } \\
\text { III } \\
\text { LOC7289 } \\
08\end{array}$ & BIRC3 & $\begin{array}{r}\text { PPPIRI5A } \\
\text { /Gadd34 }\end{array}$ & GADD45A & HSPAIA & $\begin{array}{r}\text { HSPAIA } / / / \\
\text { HSPAIB }\end{array}$ & HSPAIB & MAP3KI & MAP3KI4 & NFKBIA \\
\hline $\begin{array}{l}\text { Ta+TR vs } \\
\text { Ko_SLR }\end{array}$ & $-0,74$ & I & $-1,45$ & 1,55 & 1,46 & 2,54 & 3,28 & 2,45 & $-0,04$ & I & 2,47 \\
\hline $\begin{array}{l}\text { TR50 vs } \\
\text { Ko_SLR }\end{array}$ & 1,19 & 0,43 & I & I & 1 & 1 & 1 & I & 1 & I & 1,17 \\
\hline $\begin{array}{l}\text { Ta250 vs } \\
\text { Ko_SLR }\end{array}$ & $-0,55$ & $-0,28$ & 1 & 0,95 & $\mathrm{I}, 33$ & 2,49 & 2,99 & 2,06 & 1 & $-1,35$ & 2,03 \\
\hline $\begin{array}{l}\text { Ta+TR vs } \\
\text { TR50_SLR }\end{array}$ & $-1,95$ & & $-2,32$ & 1,22 & 1,55 & 2,61 & 2,96 & 2,44 & $-1,32$ & $-1,34$ & 1,3 \\
\hline $\begin{array}{l}\text { Ta+TR vs } \\
\text { Ta250_SL } \\
\text { R }\end{array}$ & I & 0,49 & I & 0,61 & 1 & I & 0,25 & 0,43 & 1 & I & 0,45 \\
\hline
\end{tabular}

b: Summary of the selected candidate genes' rtPCR data. The correlation with the findings of the microarray is high except for ARGHGDIA.

\begin{tabular}{|c|c|c|c|c|c|c|c|c|c|}
\hline $\begin{array}{l}\text { Taqman } \\
\text { assay }\end{array}$ & $\begin{array}{r}\mathrm{Hs} 009769 \\
24 \_\mathrm{gl}\end{array}$ & $\begin{array}{r}\mathrm{Hs} 00 \mathrm{I} 54 \mathrm{I} \\
09 \_\mathrm{ml}\end{array}$ & $\begin{array}{r}\mathrm{Hs} 00 \mathrm{I} 695 \\
85 \_\mathrm{ml}\end{array}$ & $\begin{array}{r}\mathrm{Hs} 00 \mathrm{I} 692 \\
55 \_\mathrm{ml}\end{array}$ & $\begin{array}{r}\mathrm{Hs} 0035916 \\
\text { 3_sl }\end{array}$ & $\begin{array}{r}\mathrm{Hs} 0 \mathrm{I} 0405 \\
0 \mathrm{I}+\mathrm{sH}\end{array}$ & $\begin{array}{r}\mathrm{Hs} 0 \mathrm{I} 0897 \\
53\end{array}$ & $\begin{array}{r}\mathrm{Hs} 003948 \\
90 \_\mathrm{ml}\end{array}$ & $\begin{array}{r}\mathrm{Hs} 00 \mathrm{I} 532 \\
83 \_\mathrm{ml}\end{array}$ \\
\hline $\begin{array}{l}\text { Gene } \\
\text { Symbol } \\
\text { SLR = } \\
\log 2(R Q)\end{array}$ & $\begin{array}{r}\text { ARGHGDI } \\
A\end{array}$ & BIRC3 & GADD34 & $\begin{array}{r}\text { GADD45 } \\
\mathrm{A}\end{array}$ & HSPAIA & HSPAIB & MAP3KI4 & MAP3KI & NFKBIA \\
\hline $\begin{array}{l}\text { TA+Tr vs } \\
\text { Control }\end{array}$ & $-0,4205$ & $-1,1638$ & 1,2819 & 2,4504 & 3,8893 & $3,156 \mid$ & $-0,8706$ & $-0,5410$ & 2,3151 \\
\hline $\begin{array}{l}\text { TR50 vs } \\
\text { Control }\end{array}$ & $-0,1207$ & I, I527 & 0,2107 & 0,7523 & 0,4395 & 0,4545 & 0,1833 & 0,0203 & I,5287 \\
\hline $\begin{array}{l}\text { TA25 vs } \\
\text { Control }\end{array}$ & 0,0120 & $-0,3926$ & I,4327 & 2,8888 & 3,6653 & 3,5939 & $-0,7547$ & $-0,1194$ & 2,5517 \\
\hline $\begin{array}{l}\text { TA+Tr vs } \\
\text { TR50 }\end{array}$ & $-0,2998$ & $-2,3165$ & 1,0712 & 1,6981 & 3,4498 & 2,7016 & $-1,0539$ & $-0,5613$ & 0,7864 \\
\hline $\begin{array}{l}\text { TA+Tr vs } \\
\text { TA25 }\end{array}$ & $-0,4325$ & $-0,7712$ & $-0,1508$ & $-0,4385$ & 0,2240 & $-0,4378$ & $-0,1159$ & $-0,4217$ & $-0,2366$ \\
\hline
\end{tabular}

MCL1, that is expressed in a variety of soft tissue sarcomas and acts anti-apoptotic, was down-regulated [47].

Careful interpretation of the data revealed that many of the genes involved point to the NFKB pathway. In physiological conditions, $N F K B$ is sequestered in inactive form by inhibitory proteins like NFKBIA [48], that was found to be up-regulated by the tested substances in the microarray, the PCR and the Western Blot analysis. Activation of the TNF-alpha pathway was shown to be more efficient inducing apoptosis when the NFKB pathway was blocked simultaneously [49] and could be a reason for enhanced apoptosis in the co-treatment with TRAIL and TRD.

In recent studies, tumor invasiveness could be significantly reduced in HT1080 cells by reducing NFKB activity [30] and NFKB inhibition could sensitise cells to TNF mediated cell death, probably by inhibiting the inactivating effect on JNK [50].

NFKB is activated TRADD-, TRAF3- and FADD-dependently [38] and also plays a key role in the survival of tumor cells by inducing expression of anti-apoptotic genes such 


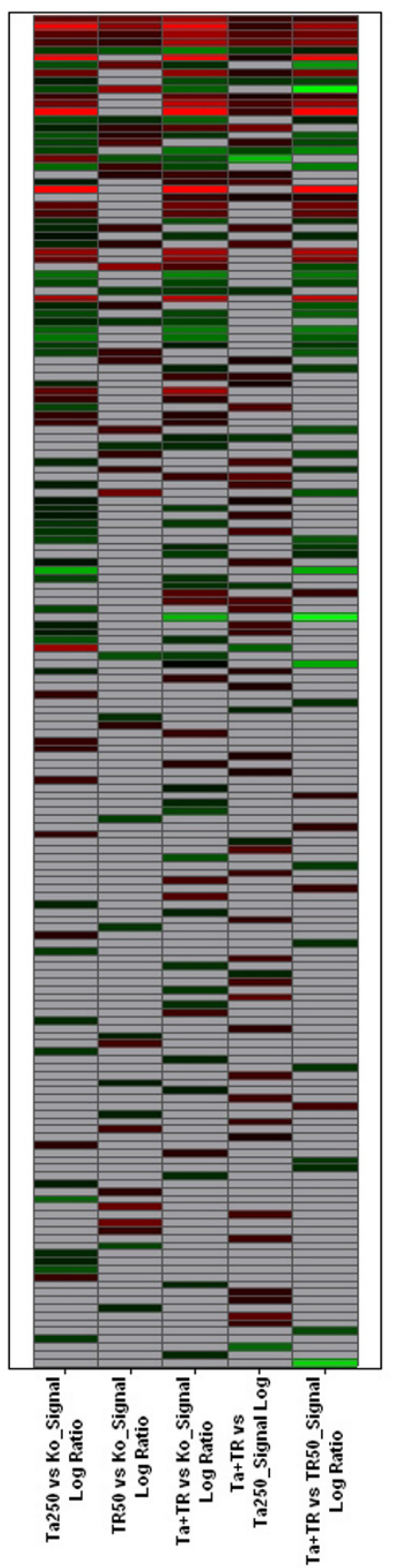

\section{Figure 6}

Overall expression patterns of 174 reliably measured probe sets associated with apoptosis out 621 apoptosis associated probe sets of the HG-UI33A_2.0 chip. Horizontal rows represent individual probe sets/genes; vertical columns represent individual samples (from left to right: Colour range: Brightest red: Signal Log Ratio (SLR) >= 2 (indicates expression level above compared sample); brightest green: $\mathrm{SLR}<=$ 2 (indicates expression level below compared sample); black: $\mathrm{SLR}=0$ (indicates unchanged expression); grey: no reliable filter target.

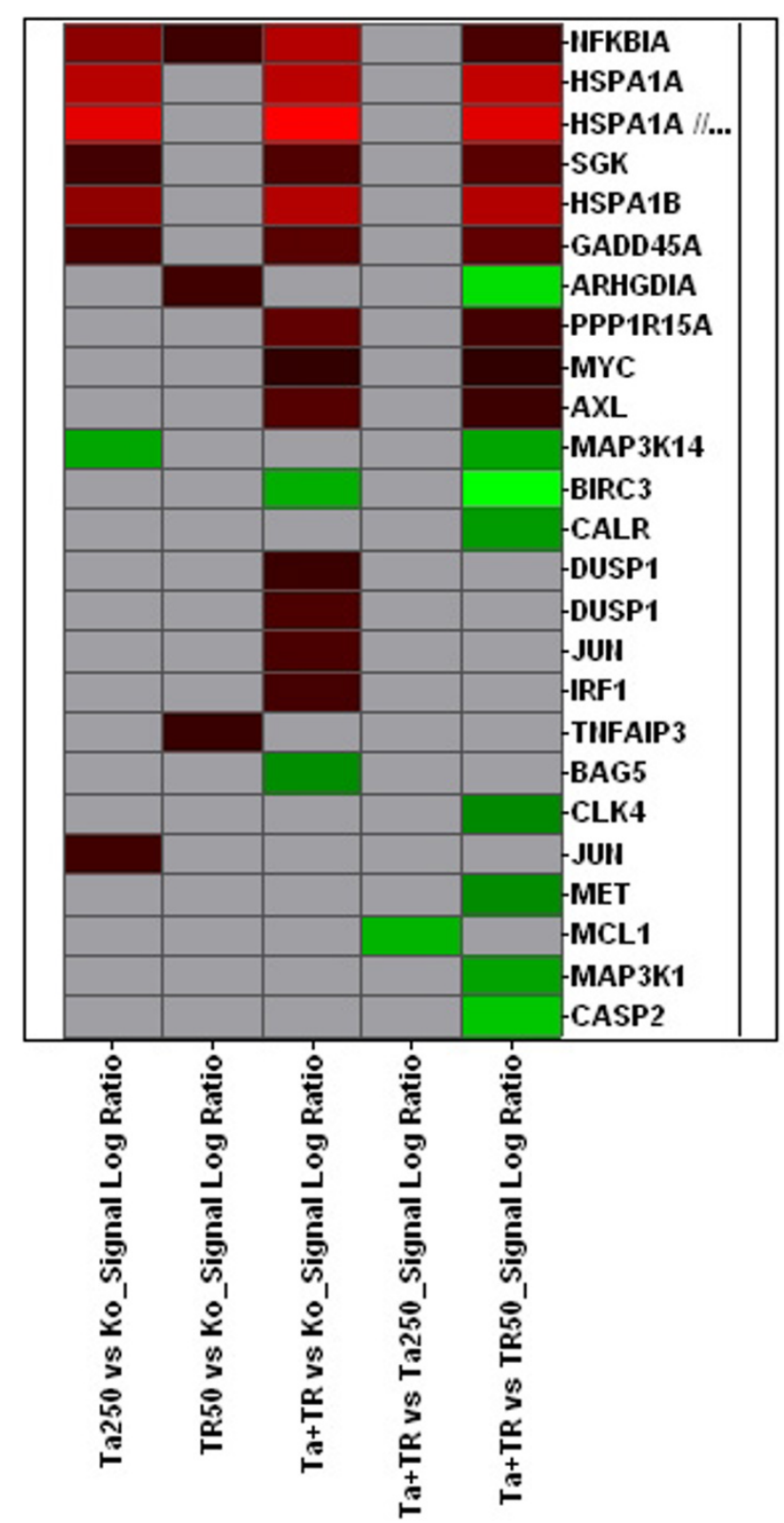

Figure 7

Overall expression patterns of 25 reliably measured probe sets associated with apoptosis out 621 apoptosis associated probe sets of the HG-UI33A_2.0 chip. Horizontal rows represent individual probe sets/genes; vertical columns represent individual samples (from left to right: Colour range:

Brightest red: Signal Log Ratio (SLR) >= 2 (indicates expression level above compared sample); brightest green: $\mathrm{SLR}<=$ 2 (indicates expression level below compared sample); black: $\mathrm{SLR}=0$ (indicates unchanged expression); grey: no reliable filter target. 

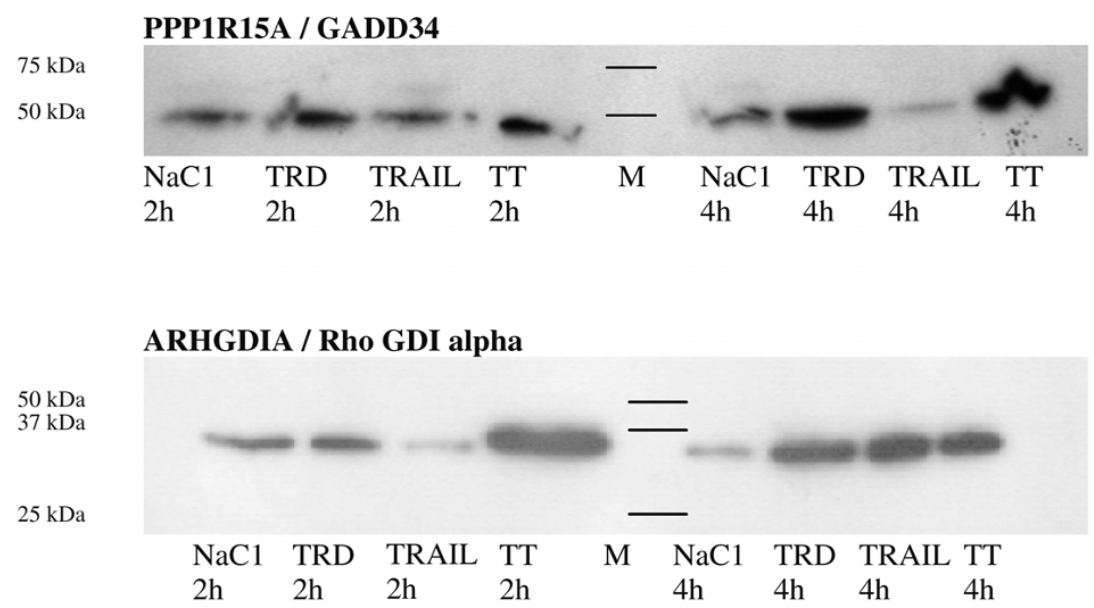

\section{NFKBIA / IkappaB-alpha}

$50 \mathrm{kDa}$

$37 \mathrm{kDa}$

$25 \mathrm{kDa}$

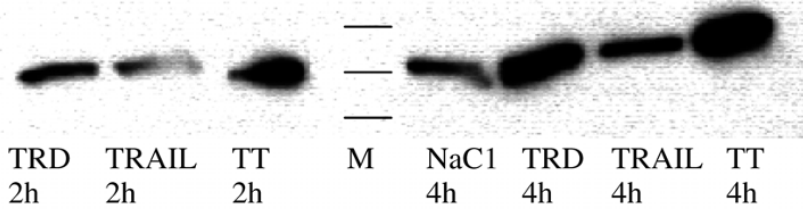

$\begin{array}{lllllllll}\mathrm{NaC} 1 & \text { TRD } & \text { TRAIL } & \text { TT } & \mathrm{M} & \mathrm{NaC} 1 & \mathrm{TRD} & \text { TRAIL } & \text { TT } \\ 2 \mathrm{~h} & 2 \mathrm{~h} & 2 \mathrm{~h} & 2 \mathrm{~h} & & 4 \mathrm{~h} & 4 \mathrm{~h} & 4 \mathrm{~h} & 4 \mathrm{~h}\end{array}$

\section{GADD 45}

$20 \mathrm{kDa}$

$15 \mathrm{kDa}$

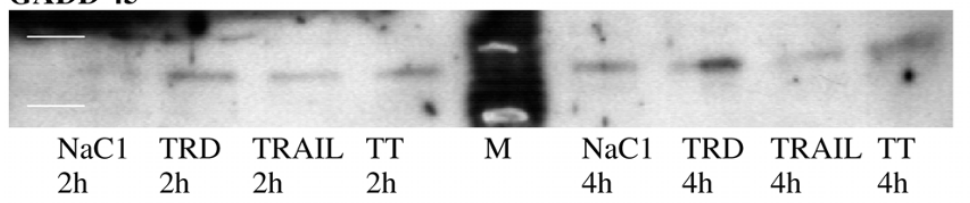

\section{BIRC3 / c-IAP2}

$75 \mathrm{kDa}$

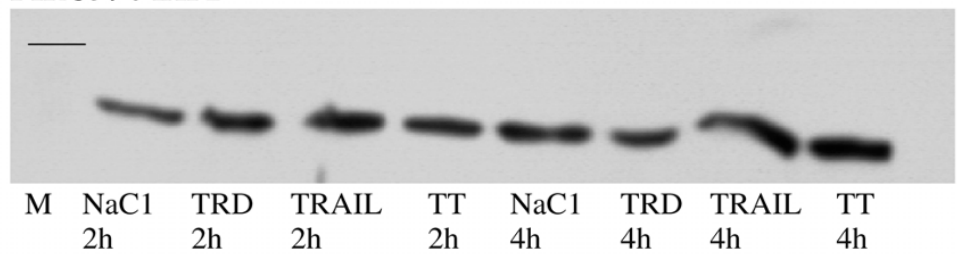

MAP3K14 / NIK

$100 \mathrm{kDa}$

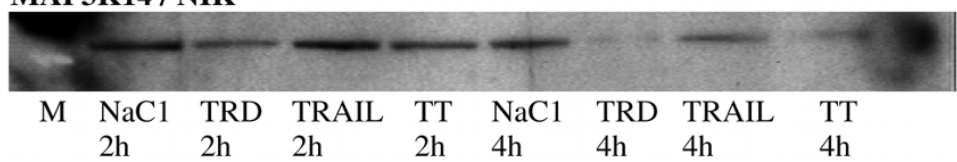

Figure 8

Representative Western Blot results for selected cytosolic proteins ( $M=$ marker, indicated by lines) after 2 and $4 \mathrm{~h}$. 

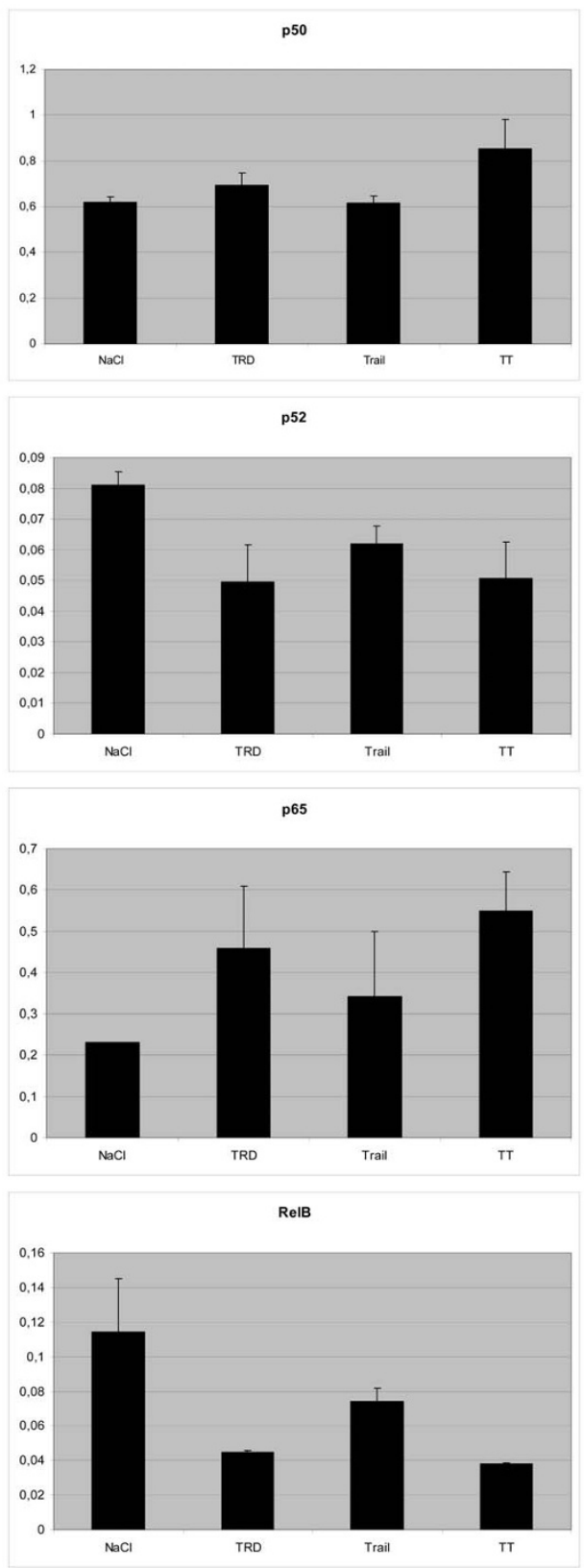

c-Rel

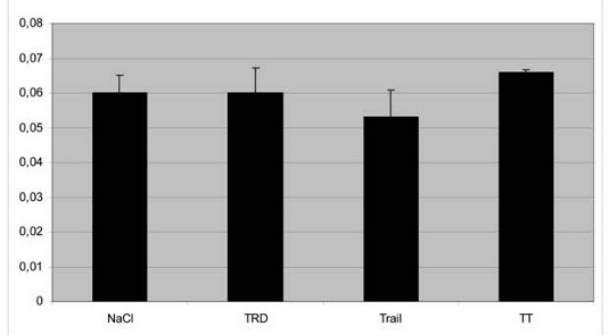

Figure 9

Diagram showing the results of the NFKB-ELISA including the standard deviation of three separate measurements. as $B c l 2, B c l 2 l 1$, vascular endothelial growth factor (VEGF), and X-linked inhibitor of apoptosis (XIAP). Out of TRADD, TRAF3, FADD, Bcl2, and Bcl2l1, microarray analysis in this study could only detect changed expression for FADD and Bcl2l1. FADD was down-regulated by the TRAIL and TRD combination and Bcl2l1 was up-regulated by TRAIL but down-regulated by TRD and the combination (tab. 1). The effect on Bcl2l1 may partly explain the synergistic effects of the substances' combination. The fact that NFKB induces the expression of cell adhesion molecules [51] could be a reason for disruption of cell adherence in our experiments.

In summary, taking the changes in gene expression, protein concentration and the results of the NFKB activity assay into account, the effects of TRD, TRAIL and the combination of the two substances seem to be closely related to NFKB and its associated pathways [8]. The changes in DNA binding activity of RelA ( $p 65$ ) and RelB, that was detected by the ELISA, may further support this assumption. RelA, $c$-Rel and RelB are known to contain C-terminal transcriptional activation domains (TADs), which enable them to activate target gene expression. In contrast, $p 50$ that was increased and $p 52$ that was found to be decreased, do not contain C-terminal TADs; therefore, $p 50$ and $p 52$ homodimers probably repress transcription unless they are bound to a protein containing a TAD, such as RelA, $c$-Rel or RelB [52,53]. Detailed knowledge about the function of these factors is scant though, especially concerning soft tissue sarcomas, so that we abstain from further interpretation.

\section{Conclusion}

TRD and TRAIL are effective to induce apoptosis and decrease proliferation in human fibrosarcoma. A variety of genes seems to be involved, pointing to the NFKB pathway as key regulator in TRD/TRAIL-mediated apoptosis.

\section{Competing interests}

The authors declare that they have no competing interests.

\section{Authors' contributions}

$\mathrm{AD}$ : developed the study design, coordinated the work, interpreted the data and prepared the manuscript. CB: carried out the experiments and interpreted the data. DB: coordinated the FACS analysis and interpreted the data. AG: established cell culture, interpreted the literature and prepared the manuscript. CG: coordinated and conceived the microscopy and interpreted the data. ML: developed the study design and corrected the manuscript. HUS: was helpful in preparing the manuscript and conceived the work. AF: did the Western Blot analysis and coordinated the laboratory work. LS: prepared the figures and coordinated cell culturing. LKH: carried out and interpreted the microarrays. UM: developed the idea, improved the study 
Table 3: Summary of the expression changes of apoptosis related genes for the single substances (TRD $250 \mu \mathrm{mol} / \mathrm{l}$, TRAIL $50 \mathrm{ng} / \mathrm{ml}$ ) compared to untreated cells and the combination therapy compared to Control, TRD and TRAIL treated cells.

\begin{tabular}{|c|c|c|c|}
\hline Gene Symbol & Gene Title & Synonyms & Gene function \\
\hline NFKBIA & $\begin{array}{l}\text { nuclear factor of kappa light } \\
\text { polypeptide gene enhancer in B- } \\
\text { cells inhibitor, alpha }\end{array}$ & $\begin{array}{l}\text { IkappaB-alpha, IkB-a, IkBa, Inhibitor of } \\
\text { kappa B-alpha, MAD3, P40 }\end{array}$ & $\begin{array}{l}\text { Proliferation in HTI } 080 \text { cells is mediated } \\
\text { through a NFKB dependent pathways }[29,54] \text {. } \\
\text { Tumor invasiveness could be significantly } \\
\text { reduced in HTI080 cells by reducing NFKB } \\
\text { activity [30]. } \\
\text { Increased NFKB activity leads to doxorubicin } \\
\text { resistance in a p53 dependent manner [28]. }\end{array}$ \\
\hline HSPAIA/B & heat shock $70 \mathrm{kDa}$ protein IA/B & HSP70, HSP72, HSPAI & $\begin{array}{l}\text { Upregulation of HSPAIA significantly increased } \\
\text { chemosensitivity of HTI } 080 \text { to mitomycin C } \\
\text { [34]. } \\
\text { The apoptogenic effects of taxanes on sarcoma } \\
\text { could be increased by co-therapy with } \\
\text { stimulators of HSPAIA expression [35]. }\end{array}$ \\
\hline SGK & $\begin{array}{l}\text { serum/glucocorticoid regulated } \\
\text { kinase }\end{array}$ & $\begin{array}{l}\text { serine/threonine-protein kinase Sgkl, } \\
\text { serum/glucocorticoid-regulated kinase I, } \\
\text { SGKI }\end{array}$ & $\begin{array}{l}\text { SGK activates the NFKB pathway and thereby } \\
\text { can prevent cells from undergoing apoptosis } \\
{[42] \text {. }}\end{array}$ \\
\hline GADD45A & $\begin{array}{l}\text { growth arrest and DNA-damage- } \\
\text { inducible, alpha }\end{array}$ & $\begin{array}{l}\text { DDITI, DNA-damage-inducible transcript } \\
\text { I, GADD45, Growth arrest and DNA- } \\
\text { damage-inducible protein, GADD45 alpha }\end{array}$ & $\begin{array}{l}\text { Upregulation of GADD45A is associated with } \\
\text { increased apoptosis and cell cycle arrest p53 } \\
\text { independently in a variety of soft tissue } \\
\text { sarcomas [37]. } \\
\text { It inhibits transcription factors associated with } \\
\text { tumor growth including the c-Jun N-terminal } \\
\text { kinase (JNK) cascade and NFKB [38,39,4I,55]. } \\
\text { For rhabdomyosarcoma, increased GADD } 45 A \\
\text { expression was associated with less aggressive } \\
\text { tumor behaviour [ } 40] \text {. } \\
\text { GADD45 may antagonize TNF-receptor } \\
\text { mediated cytotoxicity [ } 4 \text { I]. }\end{array}$ \\
\hline ARHGDIA & $\begin{array}{l}\text { Rho GDP dissociation inhibitor } \\
\text { (GDI) alpha }\end{array}$ & $\begin{array}{l}\text { GDIAI, MGCI I 7248, RHOGDI, Rho GDI } \\
\text { I, Rho-GDI alpha, Rho GDP-dissociation } \\
\text { inhibitor I }\end{array}$ & $\begin{array}{l}\text { High levels of Rho-GTP are detected in HTI080 } \\
\text { cells. The inhibition of Rho by fasudil, a Rho } \\
\text { kinase inhibitor lead to decreased tumor cell } \\
\text { motility and growth in HTI080 cells [25] and } \\
\text { associated to the development of metastases in } \\
\text { several other malignant tumors [23,24]. } \\
\text { ARHGDIA is downregulated by doxorubicin in } \\
\text { HTI080 cells [56]. }\end{array}$ \\
\hline PPPIRI5A & $\begin{array}{l}\text { protein phosphatase I, regulatory } \\
\text { (inhibitor) subunit I5A }\end{array}$ & GADD34, MyDI I6 & $\begin{array}{l}\text { Increased expression of PPPIRI5A by } \\
\text { chemosensitizers can potentiate the effects of } \\
\text { cytostatics such as platinum agents [57] and } \\
\text { probably acts p53 independently [58]. }\end{array}$ \\
\hline MYC & $\begin{array}{l}\text { v-myc myelocytomatosis viral } \\
\text { oncogene homolog (avian) }\end{array}$ & $\begin{array}{l}\text { c-Myc, Myc proto-oncogene protein, } \\
\text { transcription factor p } 64\end{array}$ & $\begin{array}{l}\text { Myc induces apoptosis by increasing the p53 } \\
\text { levels JNK-dependently [59]. }\end{array}$ \\
\hline$A X L$ & AXL receptor tyrosine kinase & $\begin{array}{l}\text { oncogene tyrosine-protein kinase } \\
\text { receptor UFO precursor, UFO }\end{array}$ & $\begin{array}{l}\text { AXL is associated with metastatic potential of } \\
\text { malignant cells by regulating adherence, motility, } \\
\text { and invasiveness [60]. } \\
\text { It can prevent cells from TNFalpha mediated } \\
\text { cell death via the phosphatidylinositol 3-kinase } \\
\text { [6I] and the NFKB pathway [62]. }\end{array}$ \\
\hline MAP3KI4 & $\begin{array}{l}\text { mitogen-activated protein kinase } \\
\text { kinase kinase } 14\end{array}$ & $\begin{array}{l}\text { FTDCRIB, HS, HsNIK, HSNIK, mitogen- } \\
\text { activated protein kinase kinase kinase I4, } \\
\text { NF-kappa beta-inducing kinase, NIK, } \\
\text { serine/threonine-protein kinase NIK }\end{array}$ & $\begin{array}{l}\text { MAP3K I } 4 \text { is a member of the TNF-Pathway and } \\
\text { activates NFKB (IKKalpha) [46]. The MAPkinase } \\
\text { pathway can induce apoptosis by induction of } \\
\text { the GADD family of genes (GADD 34, GADD } \\
\text { 45) [63]. }\end{array}$ \\
\hline BIRC3 & baculoviral IAP repeat-containing 3 & $\begin{array}{l}\text { AIPI, API2, apoptosis inhibitor 2, } \\
\text { Baculoviral IAP repeat-containing protein } \\
\text { 3, cIAP2, CIAP2, C-IAP2, HAIPI, HIAPI, } \\
\text { hiap-I, HIAP-I, IAPI, IAP homolog C, } \\
\text { inhibitor of apoptosis protein I, MALT2, } \\
\text { MIHC, RNF49, TNFR2-TRAF signalling } \\
\text { complex protein I }\end{array}$ & $\begin{array}{l}\text { BIRC3 is associated with chemotherapy } \\
\text { resistance in Ewing sarcoma, } \\
\text { rhabdomyosarcoma [64] and prostatic cancer } \\
\text { [65] and suppresses TNFalpha mediated cell } \\
\text { death by preventing formation of TNF Receptor } \\
\text { I. It regulates pro-survival NFKB-signalling by } \\
\text { promoting degradation of MAP3KI4 [66]. }\end{array}$ \\
\hline
\end{tabular}


Table 3: Summary of the expression changes of apoptosis related genes for the single substances (TRD $250 \mu \mathrm{mol} / \mathrm{l}$, TRAIL $50 \mathrm{ng} / \mathrm{ml}$ ) compared to untreated cells and the combination therapy compared to Control, TRD and TRAIL treated cells. (Continued)

\begin{tabular}{|c|c|c|c|}
\hline CALR & calreticulin & $\begin{array}{l}\text { calregulin, calreticulin precursor, cClqR, } \\
\text { CRP55, CRTC, ERp } 60 \text {, FLJ26680, grp60, } \\
\text { HACBP, RO, SSA }\end{array}$ & $\begin{array}{l}\text { Calreticulin belongs to the family of heat shock } \\
\text { proteins and strongly binds to TRAIL [67]. } \\
\text { Calreticulin is translocated to tumor cells' } \\
\text { membranes after anthracyline therapy and } \\
\text { stimulates the anti-tumor immune response } \\
\text { [68]. }\end{array}$ \\
\hline DUSPI & dual specificity phosphatase I & $\begin{array}{l}\text { CLI00, dual specificity protein } \\
\text { phosphatase I, dual specificity protein } \\
\text { phosphatase hVHI, HVHI, MAP kinase } \\
\text { phosphatase I, MKPI, MKP-I, protein- } \\
\text { tyrosine phosphatase CLI00, PTPNI0, } \\
\text { VHI }\end{array}$ & $\begin{array}{l}\text { DUSP inactivates MAP kinases [69] and can } \\
\text { protect cells from apoptotic stimuli by } \\
\text { chemotherapeutics [70]. }\end{array}$ \\
\hline JUN & $\begin{array}{l}\text { v-jun sarcoma virus } 17 \text { oncogene } \\
\text { homolog }\end{array}$ & $\begin{array}{l}\text { activator protein I, API, P39, proto- } \\
\text { oncogene c-jun, transcription factor AP-I, } \\
\text { V-jun avian sarcoma virus } 17 \text { oncogene } \\
\text { homolog }\end{array}$ & $\begin{array}{l}\text { Jun is activated by TRAIL JNK dependently and } \\
\text { promotes apoptotic cell death in malignant cells } \\
\text { including osteosarcoma [43]. } \\
\text { Downregulation of JUN decreases the } \\
\text { expression of matrix metalloproteinases and } \\
\text { thereby cellular invasiveness in HTI } 080 \text { cells } \\
\text { [44]. This down-regulation may be mediated } \\
\text { through suppression off NFKB activation [45]. } \\
\text { JUN is known to be a product of MAP2K4- } \\
\text { activation and to mediate apoptosis by several } \\
\text { chemotherapeutics [55]. } \\
\text { upregulation of HSPAIA and JUN expression } \\
\text { Chemosensitivity of HTI080 to mitomycin C } \\
\text { could significantly be increased by [34]. }\end{array}$ \\
\hline IRFI & interferon regulatory factor I & MAR & $\begin{array}{l}\text { IRFI inhibits cell growth and induces apoptosis } \\
\text { via activation of caspases I and } 7 \text { [7I]. It inhibits } \\
\text { NFKB-dependent activation of matrix } \\
\text { metalloproteinase-9 (MMP9) [72]. }\end{array}$ \\
\hline TNFAIP3 & $\begin{array}{l}\text { tumor necrosis factor, alpha- } \\
\text { induced protein } 3\end{array}$ & $\begin{array}{l}\text { A20, MGCI04522, MGCI } 38687, \\
\text { MGCI } 38688, \text { Putative DNA-binding } \\
\text { protein A20, TNFAIP2, Zinc finger } \\
\text { protein A20 }\end{array}$ & $\begin{array}{l}\text { TNFAIP3 down-regulates the TNF- } \alpha \text {-induced } \\
\text { NFKB signalling pathway [26] and reduces TNF } \\
\text { mediated apoptosis and necrosis [27]. }\end{array}$ \\
\hline BAG5 & BCL2-associated athanogene 5 & $\begin{array}{l}\text { BAG-5, BAG family molecular chaperone } \\
\text { regulator } 5 \text {, KIAA0873 }\end{array}$ & $\begin{array}{l}\text { BAG family members inhibit } \mathrm{Hsp} 70 \text { and } \\
\text { promote cell growth and survival [73]. }\end{array}$ \\
\hline CLK4 & CDC-like kinase 4 & Dual specificity protein kinase CLK4 & $\begin{array}{l}\text { CLK family members prevent cells from } \\
\text { undergoing intrinsic apoptosis [74]. }\end{array}$ \\
\hline MET & $\begin{array}{l}\text { met proto-oncogene } \\
\text { (hepatocyte growth factor } \\
\text { receptor) }\end{array}$ & $\begin{array}{l}\text { c-Met, Hepatocyte growth factor } \\
\text { receptor precursor, HGF/SF receptor, } \\
\text { HGFR, HGF receptor, Met proto- } \\
\text { oncogene tyrosine kinase, RCCP2, Scatter } \\
\text { factor receptor, SF receptor }\end{array}$ & $\begin{array}{l}\text { Over-expression of MET was associated with } \\
\text { enhanced proliferation and aggressive tumor } \\
\text { biology in sarcomas[75]. Survival, anchorage } \\
\text { dependent growth and invasiveness of sarcoma } \\
\text { cells are dependent on MET [76]. }\end{array}$ \\
\hline MCLI & $\begin{array}{l}\text { Myeloid cell leukemia sequence I } \\
\text { (BCL2-related) }\end{array}$ & $\begin{array}{l}\text { Bcl-2-related protein EAT/mcll, EAT, } \\
\text { Induced myeloid leukemia cell } \\
\text { differentiation protein Mcl-I, mcll/EAT, } \\
\text { MCLIL, MCLIS, MGC 104264, MGCI839, } \\
\text { TM }\end{array}$ & $\begin{array}{l}\text { MCLI is expressed in a variety of soft tissue } \\
\text { sarcomas and acts anti-apoptotic. Inhibition of } \\
\text { MCLI in combination with low dose } \\
\text { cyclophosphamide significantly increases } \\
\text { apoptosis in HTI080 cells [47]. }\end{array}$ \\
\hline MAP3KI & $\begin{array}{l}\text { mitogen-activated protein kinase } \\
\text { kinase kinase I }\end{array}$ & $\begin{array}{l}\text { MAPK/ERK kinase kinase I, MAPKKKI, } \\
\text { MEKK, MEKKI, MEKK I, MEK kinase I }\end{array}$ & $\begin{array}{l}\text { MEKK is activating MAPK and JNK. Reduction } \\
\text { of MEKK activity amplifies the apoptotic effect } \\
\text { of TNFalpha on fibrosarcoma cells [77]. }\end{array}$ \\
\hline CASP2 & $\begin{array}{l}\text { caspase 2, apoptosis-related } \\
\text { cysteine peptidase (neural } \\
\text { precursor cell expressed, } \\
\text { developmentally down-regulated 2) }\end{array}$ & $\begin{array}{l}\text { apoptosis-related cysteine peptidase } \\
\text { (neural precursor cell expressed, } \\
\text { developmentally down-regulated 2), } \\
\text { CASP-2, Caspase-2 precursor, ICHI, } \\
\text { ICH-IL, ICH-IL/IS, ICH-I protease, } \\
\text { NEDD2 }\end{array}$ & $\begin{array}{l}\text { Casp2 is a member of the caspases family and } \\
\text { mediates apoptotic cell death NFKB and Jun } \\
\text { dependently but independent from Fas [78]. }\end{array}$ \\
\hline
\end{tabular}

Signal log ratios of the changes are given for the several samples (TRD vs control, TRAIL vs control, TRD/TRAIL vs control, TRD/TRAIL vs TRD), signal log ratio of I representing a twofold increase, one of $-I$, that the expression is half of the expression of the control group and so forth. 
design and coordinated the work. WU: gave substantial contribution to the manuscript and the study design. AMC: carried out statistical analyses, have given substantial contribution to conception and design as well manuscript preparation.

\section{Acknowledgements}

We thank Amanda Daigeler for the formal English revision of the manuscript.

The authors thank Prof. Dr. W. E. Schmidt (Department of Medicine I, St. Josef Hospital, Ruhr-University of Bochum) and Prof. Dr. A. Muegge (Department of Medicine II, St. Josef Hospital, Ruhr-University of Bochum) for generously supporting our studies. Furthermore, they thank Annegret Flier, Illka Werner, Kirsten Mros and Rainer Lebert for technical assistance and Jan Roschinsky for statistical analysis. This study was supported by FoRUM Project F544 E-2007 from the Ruhr-University Bochum, Germany.

\section{References}

I. Singer S, Corson JM, Demetri GD, Healey EA, Marcus K, Eberlein TJ: Prognostic factors predictive of survival for truncal and retroperitoneal soft-tissue sarcoma. Ann Surg 1995, 22I(2): $185-195$.

2. Donato Di Paola E, Nielsen OS: The EORTC soft tissue and bone sarcoma group. European Organisation for Research and Treatment of Cancer. Eur J Cancer 2002, 38(Suppl 4):SI 38-SI4I.

3. Nagane M, Huang HJ, Cavenee WK: The potential of TRAIL for cancer chemotherapy. Apoptosis 200I, 6(3):19I-197.

4. Leaman DW, Chawla-Sarkar M, Vyas K, Reheman M, Tamai K, Toji S, Borden EC: Identification of $\mathbf{X}$-linked inhibitor of apoptosisassociated factor-I as an interferon-stimulated gene that augments TRAIL Apo2L-induced apoptosis. J Biol Chem 2002, 277(32):28504-285II.

5. Ogasawara J, Watanabe-Fukunaga R, Adachi M, Matsuzawa A, Kasugai T, Kitamura Y, Itoh N, Suda T, Nagata S: Lethal effect of the antiFas antibody in mice. Nature 1993, 364(6440):806-809.

6. Tsai WS, Yeow WS, Chua A, Reddy RM, Nguyen DM, Schrump DS, Nguyen DM: Enhancement of Apo2L/TRAIL-mediated cytotoxicity in esophageal cancer cells by cisplatin. Mol Cancer Ther 2006, 5( ( 2 2):2977-2990.

7. Kondo K, Yamasaki S, Inoue N, Sugie T, Teratani N, Kan T, Shimada $Y$ : Prospective antitumor effects of the combination of tumor necrosis factor-related apoptosis-inducing ligand (TRAIL) and cisplatin against esophageal squamous cell carcinoma. Surg Today 2006, 36(I I):966-974.

8. Dalen H, Neuzil J: Alpha-tocopheryl succinate sensitises a $\mathbf{T}$ lymphoma cell line to TRAIL-induced apoptosis by suppressing NF-kappaB activation. Br J Cancer 2003, 88(I): $153-158$.

9. Weber T, Lu M, Andera L, Lahm H, Gellert N, Fariss MW, Korinek V, Sattler W, Ucker DS, Terman A, et al.: Vitamin E succinate is a potent novel antineoplastic agent with high selectivity and cooperativity with tumor necrosis factor-related apoptosisinducing ligand (Apo2 ligand) in vivo. Clin Cancer Res 2002, 8(3):863-869.

10. Braumann C, Henke W, Jacobi CA, Dubiel W: The tumor-suppressive reagent taurolidine is an inhibitor of protein biosynthesis. Int J Cancer 2004, I I 2(2):225-230.

II. Calabresi P, Goulette FA, Darnowski JW: Taurolidine: cytotoxic and mechanistic evaluation of a novel antineoplastic agent. Cancer Res 200I, 6 I ( 1 8):6816-682I.

12. McCourt M, Wang JH, Sookhai S, Redmond HP: Taurolidine inhibits tumor cell growth in vitro and in vivo. Ann Surg Oncol 2000, 7(9):685-69l.

13. Braumann C, Winkler G, Rogalla P, Menenakos C, Jacobi CA: Prevention of disease progression in a patient with a gastric cancer-re-recurrence. Outcome after intravenous treatment with the novel antineoplastic agent taurolidine. Report of a case. World J Surg Oncol 2006, 4:34.

14. Stendel R, Scheurer L, Schlatterer K, Stalder U, Pfirrmann RW, Fiss I, Mohler H, Bigler L: Pharmacokinetics of taurolidine following repeated intravenous infusions measured by HPLC-ESI-MSI
MS of the derivatives taurultame and taurinamide in glioblastoma patients. Clin Pharmacokinet 2007, 46(6):513-524.

15. Stendel R, Scheurer L, Stoltenburg-Didinger G, Brock M, Mohler H: Enhancement of Fas-ligand-mediated programmed cell death by taurolidine. Anticancer Res 2003, 23(3B):2309-23 I4.

16. Monson JR, Ramsey PS, Donohue JH: Taurolidine inhibits tumour necrosis factor (TNF) toxicity - new evidence of TNF and endotoxin synergy. Eur J Surg Oncol I993, 19(3):226-23I.

17. Han Z, Ribbizi I, Pantazis P, Wyche J, Darnowski J, Calabresi P: The antibacterial drug taurolidine induces apoptosis by a mitochondrial cytochrome c-dependent mechanism. Anticancer Res 2002, 22(4): 1959-1964.

18. Ribizzi I, Darnowski JW, Goulette FA, Akhtar MS, Chatterjee D, Calabresi P: Taurolidine: preclinical evaluation of a novel, highly selective, agent for bone marrow purging. Bone Marrow Transplant 2002, 29(4):313-319.

19. Jacobi CA, Menenakos C, Braumann C: Taurolidine - a new drug with anti-tumor and anti-angiogenic effects. Anticancer Drugs 2005, 16(9):917-921.

20. Chromik AM, Daigeler A, Hilgert C, Bulut D, Geisler A, Liu V, Otte JM, Uhl W, Mittelkotter U: Synergistic effects in apoptosis induction by taurolidine and TRAIL in HCT-I5 colon carcinoma cells. J Invest Surg 2007, 20(6):339-348.

21. Daigeler A, Chromik AM, Geisler A, Bulut D, Hilgert C, Krieg A, Klein-Hitpass L, Lehnhardt M, Uhl W, Mittelkotter U: Synergistic apoptotic effects of taurolidine and TRAIL on squamous carcinoma cells of the esophagus. Int J Oncol 2008, 32(6): $1205-1220$.

22. Tomek S, Koestler W, Horak P, Grunt T, Brodowicz T, Pribill I, Halaschek J, Haller G, Wiltschke C, Zielinski CC, et al.: Trailinduced apoptosis and interaction with cytotoxic agents in soft tissue sarcoma cell lines. Eur J Cancer 2003, 39(9): $1318-1329$.

23. de Angelis PM, Fjell B, Kravik KL, Haug T, Tunheim SH, Reichelt W, Beigi M, Clausen OP, Galteland E, Stokke T: Molecular characterizations of derivatives of HCTI 16 colorectal cancer cells that are resistant to the chemotherapeutic agent 5 -fluorouracil. Int J Oncol 2004, 24(5): 1279-1288.

24. Ota T, Maeda M, Suto S, Tatsuka M: LyGDI functions in cancer metastasis by anchoring Rho proteins to the cell membrane. Mol Carcinog 2004, 39(4):206-220.

25. Ying H, Biroc SL, Li WW, Alicke B, Xuan JA, Pagila R, Ohashi Y, Okada T, Kamata $Y$, Dinter H: The Rho kinase inhibitor fasudil inhibits tumor progression in human and rat tumor models. Mol Cancer Ther 2006, 5(9):2158-2164.

26. Cooper JT, Stroka DM, Brostjan C, Palmetshofer A, Bach FH, Ferran C: A20 blocks endothelial cell activation through a NF-kappaB-dependent mechanism. J Biol Chem 1996, 27I(30): | 8068- I8073.

27. Heyninck K, Denecker G, De Valck D, Fiers W, Beyaert R: Inhibition of tumor necrosis factor-induced necrotic cell death by the zinc finger protein A20. Anticancer Res 1999, 19(4B):2863-2868.

28. Hu Q, Zhou MX, Liu SY, Zhang LQ, Liu AQ, Guo Y], Song Y: [Regulation of NF-kappaB/P65 by MDM2 in acute lymphoblastic leukemia in childhood]. Zhonghua $\mathrm{Er} \mathrm{Ke} \mathrm{Za} \mathrm{Zhi} \mathrm{2003,}$ 4I(I 2):92I-924.

29. Park HJ, Chung HJ, Min HY, Park EJ, Hong JY, Kim WB, Kim SH, Lee SK: Inhibitory effect of DA-125, a new anthracyclin analog antitumor agent, on the invasion of human fibrosarcoma cells by down-regulating the matrix metalloproteinases. Biochem Pharmacol 2005, 7 I (I-2):2I-3I.

30. Park JM, Kim A, Oh JH, Chung AS: Methylseleninic acid inhibits PMA-stimulated pro-MMP-2 activation mediated by MTIMMP expression and further tumor invasion through suppression of NF-kappaB activation. Carcinogenesis 2007, 28(4):837-847.

31. Walters DK, Muff R, Langsam B, Gruber P, Born W, Fuchs B: Taurolidine: a novel anti-neoplastic agent induces apoptosis of osteosarcoma cell lines. Invest New Drugs 2007, 25(4):305-3I 2.

32. Marcinkiewicz J, Kurnyta M, Biedron R, Bobek M, Kontny E, Maslinski $W$ : Anti-inflammatory effects of taurine derivatives (taurine chloramine, taurine bromamine, and taurolidine) are mediated by different mechanisms. Adv Exp Med Biol 2006, 583:48I-492. 
33. Bobrich E, Braumann C, Opitz I, Menenakos C, Kristiansen G, Jacobi $\mathrm{CA}$ : Influence of intraperitoneal application of taurolidine/ heparin on expression of adhesion molecules and colon cancer in rats undergoing laparoscopy. J Surg Res 2007, 137(1):75-82.

34. Nakatsu N, Yoshida $Y$, Yamazaki K, Nakamura T, Dan S, Fukui $Y$, Yamori T: Chemosensitivity profile of cancer cell lines and identification of genes determining chemosensitivity by an integrated bioinformatical approach using cDNA arrays. Mol Cancer Ther 2005, 4(3):399-4I2.

35. Gehrmann M: Drug evaluation: STA-4783 - enhancing taxane efficacy by induction of Hsp70. Curr Opin Investig Drugs 2006, 7(6):574-580

36. Schuller-Levis GB, Park E: Taurine: new implications for an old amino acid. FEMS Microbiol Lett 2003, 226(2): 195-202.

37. Zhu QS, Ren W, Korchin B, Lahat G, Dicker A, Lu Y, Mills G, Pollock RE, Lev D: Soft tissue sarcoma cells are highly sensitive to AKT blockade: a role for $\mathrm{p} 53$-independent up-regulation of GADD45 alpha. Cancer Res 2008, 68(8):2895-2903.

38. Jin Z, El-Deiry WS: Distinct signaling pathways in TRAIL-versus tumor necrosis factor-induced apoptosis. Mol Cell Biol 2006, 26(2I):8|36-8|48.

39. Mikami T, Koyama T, Koyama T, Imakiire A, Yamamoto K, Furuhata $\mathrm{M}$, Toyota $\mathrm{H}$, Mizuguchi J: $\mathbf{C}$-jun $\mathbf{N}$-terminal kinase activation is required for apoptotic cell death induced by TNF-related apoptosis-inducing ligand plus DNA-damaging agents in sarcoma cell lines. Anticancer Res 2006, 26(2A): $1153-1160$.

40. Kappler R, Bauer R, Calzada-Wack J, Rosemann M, Hemmerlein B, $\mathrm{Hahn} \mathrm{H}$ : Profiling the molecular difference between Patchedand p53-dependent rhabdomyosarcoma. Oncogene 2004, 23(54):8785-8795.

4I. Papa S, Zazzeroni F, Bubici C, Jayawardena S, Alvarez K, Matsuda S, Nguyen DU, Pham CG, Nelsbach AH, Melis T, et al.: Gadd45 beta mediates the NF-kappa B suppression of JNK signalling by targeting MKK7/JNKK2. Nat Cell Biol 2004, 6(2): I 46-I53.

42. Zhang L, Cui R, Cheng $X$, Du J: Antiapoptotic effect of serum and glucocorticoid-inducible protein kinase is mediated by novel mechanism activating I\{kappa\}B kinase. Cancer Res 2005, 65(2):457-464.

43. Mikami T, Koyama T, Imakiire A, Yamamoto K, Furuhata M, Toyota $\mathrm{H}$, Mizuguchi J: $\mathbf{C}$-jun $\mathbf{N}$-terminal kinase activation is required for apoptotic cell death induced by TNF-related apoptosisinducing ligand plus DNA-damaging agents in sarcoma cell lines. Anticancer Res 2006, 26(2A): I I53-II 60.

44. Rajapakse N, Kim MM, Mendis E, Huang R, Kim SK: Carboxylated chitooligosaccharides (CCOS) inhibit MMP-9 expression in human fibrosarcoma cells via down-regulation of AP-I. Biochim Biophys Acta 2006, I 760( I 2): I780-1788.

45. Park BC, Thapa D, Lee YS, Kwak MK, Lee ES, Choi HG, Yong CS, Kim JA: I-furan-2-yl-3-pyridin-2-yl-propenone inhibits the invasion and migration of $\mathrm{HT} 1080$ human fibrosarcoma cells through the inhibition of proMMP-2 activation and down regulation of MMP-9 and MTI-MMP. Eur J Pharmacol 2007, 567(3): I 93-197.

46. Senftleben U, Cao Y, Xiao G, Greten FR, Krahn G, Bonizzi G, Chen $Y$, Hu Y, Fong A, Sun SC, et al.: Activation by IKKalpha of a second, evolutionary conserved, NF-kappa B signaling pathway. Science 200I, 293(5534): I 495-I499.

47. Thallinger $\mathrm{C}$, Wolschek MF, Maierhofer $\mathrm{H}$, Skvara $\mathrm{H}$, Pehamberger $\mathrm{H}$, Monia BP, Jansen B, Wacheck V, Selzer E: Mcl-I is a novel therapeutic target for human sarcoma: synergistic inhibition of human sarcoma xenotransplants by a combination of $\mathrm{mcl}-\mathrm{I}$ antisense oligonucleotides with low-dose cyclophosphamide. Clin Cancer Res 2004, IO( I 2 Pt I):4 I85-4I9I.

48. Shukla S, Gupta S: Suppression of constitutive and tumor necrosis factor alpha-induced nuclear factor (NF)-kappaB activation and induction of apoptosis by apigenin in human prostate carcinoma PC-3 cells: correlation with down-regulation of NF-kappaB-responsive genes. Clin Cancer Res 2004, I0(9):3169-3178.

49. Wang CY, Mayo MW, Baldwin AS Jr: TNF- and cancer therapyinduced apoptosis: potentiation by inhibition of NF-kappaB. Science 1996, 274(5288):784-787.

50. Javelaud D, Besancon F: NF-kappa B activation results in rapid inactivation of JNK in TNF alpha-treated Ewing sarcoma cells: a mechanism for the anti-apoptotic effect of NF-kappa B. Oncogene 200I, 20(32):4365-4372.
51. Escarcega RO, Fuentes-Alexandro S, Garcia-Carrasco M, Gatica A Zamora A: The transcription factor nuclear factor-kappa B and cancer. Clin Oncol (R Coll Radiol) 2007, 19(2):154-|6I.

52. Hoffmann A, Natoli G, Ghosh G: Transcriptional regulation via the NF-kappaB signaling module. Oncogene 2006, 25(5I):6706-67I6.

53. Tergaonkar V: NFkappaB pathway: a good signaling paradigm and therapeutic target. Int J Biochem Cell Biol 2006, 38(10): 1647-1653.

54. Campbell KJ, O'Shea JM, Perkins ND: Differential regulation of NF-kappaB activation and function by topoisomerase II inhibitors. BMC Cancer 2006, 6:101.

55. Lauricella M, Emanuele S, D'Anneo A, Calvaruso G, Vassallo B, Carlisi D, Portanova P, Vento R, Tesoriere G: JNK and AP-I mediate apoptosis induced by bortezomib in HepG2 cells via FasL/ caspase-8 and mitochondria-dependent pathways. Apoptosis 2006, II (4):607-625.

56. Lehnhardt M, Klein-Hitpass L, Kuhnen C, Homann HH, Daigeler A, Steinau HU, Roehrs S, Schnoor L, Steinstraesser L, Mueller O: Response rate of fibrosarcoma cells to cytotoxic drugs on the expression level correlates to the therapeutic response rate of fibrosarcomas and is mediated by regulation of apoptotic pathways. BMC Cancer 2005, 5:74.

57. Fishel ML, Rabik CA, Bleibel WK, Li X, Moschel RC, Dolan ME: Role of GADD34 in modulation of cisplatin cytotoxicity. Biochem Pharmacol 2006, 71 (3):239-247.

58. Hollander MC, Zhan Q, Bae I, Fornace AJ Jr: Mammalian GADD34, an apoptosis- and DNA damage-inducible gene. J Biol Chem 1997, 272(2 I): I373।-I3737.

59. Taylor AC, Schuster K, McKenzie PP, Harris LC: Differential cooperation of oncogenes with p53 and Bax to induce apoptosis in rhabdomyosarcoma. Mol Cancer 2006, 5:53.

60. Nakano T, Tani M, Ishibashi Y, Kimura K, Park YB, Imaizumi N, Tsuda $\mathrm{H}$, Aoyagi K, Sasaki H, Ohwada S, et al.: Biological properties and gene expression associated with metastatic potential of human osteosarcoma. Clin Exp Metastasis 2003, 20(7):665-674.

6I. Shankar SL, O'Guin K, Kim M, Varnum B, Lemke G, Brosnan CF, Shafit-Zagardo B: Gas6/Axl signaling activates the phosphatidylinositol 3-kinase/Akt I survival pathway to protect oligodendrocytes from tumor necrosis factor alpha-induced apoptosis. J Neurosci 2006, 26(21):5638-5648.

62. Demarchi F, Verardo R, Varnum B, Brancolini C, Schneider C: Gas6 anti-apoptotic signaling requires NF-kappa B activation. J Biol Chem 200I, 276(34):31738-3I744.

63. Sarkar D, Su ZZ, Lebedeva IV, Sauane M, Gopalkrishnan RV, Valerie K, Dent P, Fisher PB: mda-7 (IL-24) Mediates selective apoptosis in human melanoma cells by inducing the coordinated overexpression of the GADD family of genes by means of p38 MAPK. Proc Natl Acad Sci USA 2002, 99(15): $10054-10059$.

64. Kilic M, Kasperczyk H, Fulda S, Debatin KM: Role of hypoxia inducible factor-I alpha in modulation of apoptosis resistance. Oncogene 2007, 26(14):2027-2038.

65. Nomura T, Yamasaki M, Nomura Y, Mimata H: Expression of the inhibitors of apoptosis proteins in cisplatin-resistant prostate cancer cells. Oncol Rep 2005, I 4(4):993-997.

66. Varfolomeev E, Vucic D: (Un)expected roles of c-IAPs in apoptotic and NFkappaB signaling pathways. Cell Cycle 2008, 7( I I):

67. Duus K, Pagh RT, Holmskov U, Hojrup P, Skov S, Houen G: Interaction of calreticulin with CD40 ligand, TRAIL and Fas ligand. Scand J Immunol 2007, 66(5):50I-507.

68. Chaput N, De Botton S, Obeid M, Apetoh L, Ghiringhelli F, Panaretakis T, Flament C, Zitvogel L, Kroemer G: Molecular determinants of immunogenic cell death: surface exposure of calreticulin makes the difference. I Mol Med 2007, 85(10): 1069-1076.

69. Abraham SM, Clark AR: Dual-specificity phosphatase I: a critical regulator of innate immune responses. Biochem Soc Trans 2006, 34(Pt 6): $1018-1023$

70. Vogt A, McDonald PR, Tamewitz A, Sikorski RP, Wipf P, Skoko J] 3rd, Lazo JS: A cell-active inhibitor of mitogen-activated protein kinase phosphatases restores paclitaxel-induced apoptosis in dexamethasone-protected cancer cells. Mol Cancer Ther 2008, 7(2):330-340

7I. Sanceau J, Hiscott J, Delattre O, Wietzerbin J: IFN-beta induces serine phosphorylation of Stat-I in Ewing's sarcoma cells and 
mediates apoptosis via induction of IRF-I and activation of caspase-7. Oncogene 2000, 19(30):3372-3383.

72. Sanceau J, Boyd DD, Seiki M, Bauvois B: Interferons inhibit tumor necrosis factor-alpha-mediated matrix metalloproteinase-9 activation via interferon regulatory factor- $I$ binding competition with NF-kappa B. J Biol Chem 2002, 277(38):35766-35775.

73. Clevenger CV, Thickman K, Ngo W, Chang WP, Takayama S, Reed JC: Role of Bag-I in the survival and proliferation of the cytokine-dependent lymphocyte lines, $\mathrm{Ba} / \mathrm{F3}$ and $\mathrm{Nb2}$. Mol Endocrinol 1997, II(5):608-618.

74. Takahashi M, Shimizu T, Moriizumi E, Shirasawa T: Clk-I deficiency induces apoptosis associated with mitochondrial dysfunction in mouse embryos. Mech Ageing Dev 2008, I 29(5):291-298.

75. Rong S, Jeffers M, Resau JH, Tsarfaty I, Oskarsson M, Woude GF Vande: Met expression and sarcoma tumorigenicity. Cancer Res 1993, 53(22):5355-5360.

76. Taulli R, Scuoppo C, Bersani F, Accornero P, Forni PE, Miretti S, Grinza A, Allegra P, Schmitt-Ney M, Crepaldi T, et al:: Validation of met as a therapeutic target in alveolar and embryonal rhabdomyosarcoma. Cancer Res 2006, 66(9):4742-4749.

77. Widmann C, Johnson NL, Gardner AM, Smith RJ, Johnson GL: Potentiation of apoptosis by low dose stress stimuli in cells expressing activated MEK kinase I. Oncogene 1997, I 5(20):2439-2447.

78. Guo LL, Xiao S, Guo Y: Activation of transcription factors NFkappaB and AP-I and their relations with apoptosis associated-proteins in hepatocellular carcinoma. World J Gastroenterol 2005, I I (25):3860-3865.

Publish with Bio Med Central and every scientist can read your work free of charge

"BioMed Central will be the most significant development for disseminating the results of biomedical research in our lifetime. "

Sir Paul Nurse, Cancer Research UK

Your research papers will be:

- available free of charge to the entire biomedical community

- peer reviewed and published immediately upon acceptance

- cited in PubMed and archived on PubMed Central

- yours - you keep the copyright

Submit your manuscript here:

http://www.biomedcentral.com/info/publishing_adv.asp
BiolMedcentral 